\title{
Regulation of Eosinophilia in Asthma-New Therapeutic Approaches for Asthma Treatment
}

\author{
Ruth P. Cusack ${ }^{+}{ }^{(}$, Christiane E. Whetstone ${ }^{\dagger}$, Yanqing Xie, Maral Ranjbar and Gail M. Gauvreau * \\ Department of Medicine, McMaster University, Hamilton, ON L8S 4K1, Canada; cusackr@mcmaster.ca (R.P.C.); \\ whetstoc@mcmaster.ca (C.E.W.); xiey56@mcmaster.ca (Y.X.); ranjbm1@mcmaster.ca (M.R.) \\ * Correspondence: gauvreau@mcmaster.ca; Tel.: +1-905-525-9140 (ext. 22791) \\ + These authors contributed equally to the development of this manuscript.
}

check for updates

Citation: Cusack, R.P.; Whetstone, C.E.; Xie, Y.; Ranjbar, M.; Gauvreau, G.M. Regulation of Eosinophilia in Asthma-New Therapeutic Approaches for Asthma Treatment. Cells 2021, 10, 817. https://doi.org/ 10.3390/cells10040817

Academic Editor: Stephane Esnault

Received: 8 February 2021

Accepted: 4 April 2021

Published: 6 April 2021

Publisher's Note: MDPI stays neutral with regard to jurisdictional claims in published maps and institutional affiliations.

Copyright: (C) 2021 by the authors Licensee MDPI, Basel, Switzerland. This article is an open access article distributed under the terms and conditions of the Creative Commons Attribution (CC BY) license (https:/ / creativecommons.org/licenses/by/ $4.0 /)$.

\begin{abstract}
Asthma is a complex and chronic inflammatory disease of the airways, characterized by variable and recurring symptoms, reversible airflow obstruction, bronchospasm, and airway eosinophilia. As the pathophysiology of asthma is becoming clearer, the identification of new valuable drug targets is emerging. IL-5 is one of these such targets because it is the major cytokine supporting eosinophilia and is responsible for terminal differentiation of human eosinophils, regulating eosinophil proliferation, differentiation, maturation, migration, and prevention of cellular apoptosis. Blockade of the IL-5 pathway has been shown to be efficacious for the treatment of eosinophilic asthma. However, several other inflammatory pathways have been shown to support eosinophilia, including IL-13, the alarmin cytokines TSLP and IL-33, and the IL-3/5/GM-CSF axis. These and other alternate pathways leading to airway eosinophilia will be described, and the efficacy of therapeutics that have been developed to block these pathways will be evaluated.
\end{abstract}

Keywords: eosinophil; asthma; clinical trials; therapy; inflammatory mechanisms

\section{Introduction}

Asthma is an inflammatory condition of the airways that results in recurring symptoms such as airway obstructions, bronchial spasms, and elevated levels of eosinophils in the airways (eosinophilia). One of the hallmarks of asthma is the presence of eosinophils, which accumulate in the airways where they are believed to be an essential effector cell in the pathogenesis of the allergic disease. Migration and proliferation of eosinophils depend on the highly regulated signaling of several chemokines and cytokines. Elevated levels of the cytokines IL-3, IL-5, and GM-CSF, together with thymic stromal lymphopoietin (TSLP), IL-4, IL-13, IL-17, IL-25, IL-33, and chemokines acting through the chemokine receptor CCR3, cause extensive inflammation, mucosal remodeling, and mucus hypersecretion in the airways [1]. Despite eosinophils persisting at relatively low levels in the bloodstream, accounting for approximately $5 \%$ of the total white blood cell count in asthma [2], eosinophil counts increase drastically in the asthmatic airways after bronchoprovocation [3], and are found at high levels in airways of most patients with chronic asthma [4]. IL-5 is the major cytokine supporting eosinophilia, responsible for terminal differentiation of human eosinophils, and regulates eosinophil proliferation, differentiation, maturation, migration, and prevention of cellular apoptosis. Anti-IL-5 therapy as a method of asthma treatment has been introduced over the past decade for the treatment of severe eosinophilic asthma. However, several other inflammatory pathways have been shown to support eosinophilia, including IL-13, and most recently, the alarmin cytokines TSLP and IL-33. This review will describe the mechanisms and efficacy of various therapeutics and biologics targeting eosinophilic airway inflammatory pathways, including glucocorticosteroids, therapeutics targeting specific receptors on eosinophils, T2 cytokines, and upstream pathways. Table 1 summarizes investigational therapies that have been or are currently undergoing evaluation for treatment of asthma. 
Table 1. Eosinophil-targeted therapies.

\begin{tabular}{|c|c|c|c|c|c|c|c|c|}
\hline $\begin{array}{l}\text { Mechanism of } \\
\text { Action }\end{array}$ & Name & $\begin{array}{l}\text { Dosing and } \\
\text { Route }\end{array}$ & Adverse Events & Asthma Approval & $\begin{array}{l}\text { Current } \\
\text { Clinical Trial } \\
\text { Phase }\end{array}$ & Findings & $\begin{array}{l}\text { Other } \\
\text { Populations } \\
\text { Investigated }\end{array}$ & $\begin{array}{l}\text { Ongoing Clinical } \\
\text { Trials }\end{array}$ \\
\hline \multirow{3}{*}{$\begin{array}{l}\text { Anti-IL-5: } \\
\text { Binds to IL-5, } \\
\text { preventing IL-5 } \\
\text { from binding to } \\
\text { the receptor on } \\
\text { eosinophils }\end{array}$} & GSK3511294 & $\begin{array}{l}\text { Long-acting SC } \\
\text { injection }\end{array}$ & Unknown & $\mathrm{N} / \mathrm{A}$ & 3 & $\begin{array}{l}3 \text { Phase } 3 \text { trials } \\
\text { currently recruiting }\end{array}$ & $\begin{array}{l}\text { Mild } \\
\text { asthma-results } \\
\text { pending }\end{array}$ & $\begin{array}{l}\text { NCT04719832 } \\
\text { NCT04718103 } \\
\text { NCT04718389 }\end{array}$ \\
\hline & Mepolizumab & $\begin{array}{l}\text { Fixed dose- } \\
100 \text { mg SC every } \\
4 \text { weeks }\end{array}$ & $\begin{array}{l}\text { Rarely causes } \\
\text { hypersensitivity } \\
\text { reactions } \\
\text { Risk of herpes } \\
\text { zoster infection }\end{array}$ & $\begin{array}{l}\text { Uncontrolled } \\
\text { severe } \\
\text { eosinophilic } \\
\text { asthma aged } \\
\geq 6 \text { years }\end{array}$ & - & $\begin{array}{l}\downarrow \text { Exacerbations } \\
\sim 50 \% \\
\downarrow \text { OCS use } \\
\text { Facilitates OCS weaning } \\
\uparrow \text { FEV1 }\end{array}$ & $\begin{array}{l}\text { COPD } \\
\text { EoE }\end{array}$ & $\begin{array}{l}\text { NCT04075331 } \\
\text { NCT03656380 }\end{array}$ \\
\hline & Reslizumab & $\begin{array}{l}\text { Weight adjusted } \\
\text { dose- } 3 \mathrm{mg} / \mathrm{kg} \text { IV } \\
\text { infusion every } \\
4 \text { weeks }\end{array}$ & $\begin{array}{l}\text { Black box warning: } \\
0.3 \% \text { of patients } \\
\text { reported } \\
\text { anaphylaxis }\end{array}$ & $\begin{array}{l}\text { Uncontrolled } \\
\text { severe } \\
\text { eosinophilic } \\
\text { asthma aged } \\
\geq 18 \text { years }\end{array}$ & - & $\begin{array}{l}\downarrow \text { Exacerbations } \\
\sim 50-60 \% \\
\uparrow \text { FEV1 }\end{array}$ & EGPA & NCT02947945 \\
\hline $\begin{array}{l}\text { Anti-IL-5R: } \\
\text { Binds to the } \alpha \\
\text { subunit of the IL-5 } \\
\text { receptor on } \\
\text { eosinophils and } \\
\text { basophils resulting } \\
\text { in apoptosis }\end{array}$ & Benralizumab & $\begin{array}{l}\text { Fixed dose- } \\
30 \text { mg SC every } \\
4 \text { weeks for } \\
12 \text { weeks then } \\
\text { every } 8 \text { weeks }\end{array}$ & $\begin{array}{l}\text { Rarely causes } \\
\text { hypersensitivity } \\
\text { reactions }\end{array}$ & $\begin{array}{l}\text { Uncontrolled } \\
\text { severe } \\
\text { eosinophilic } \\
\text { asthma aged } \\
\geq 12 \text { years }\end{array}$ & - & $\begin{array}{l}\downarrow \text { Exacerbations } \\
\sim 50-70 \% \\
\downarrow \text { OCS use } \\
\text { Facilitates OCS weaning } \\
\uparrow \text { FEV1 }\end{array}$ & $\begin{array}{l}\text { Atopic Dermatitis } \\
\text { EoE }\end{array}$ & $\begin{array}{l}\text { NCT03563066 } \\
\text { NCT04543409 }\end{array}$ \\
\hline
\end{tabular}


Table 1. Cont.

\begin{tabular}{|c|c|c|c|c|c|c|c|c|}
\hline $\begin{array}{l}\text { Mechanism of } \\
\text { Action }\end{array}$ & Name & $\begin{array}{l}\text { Dosing and } \\
\text { Route }\end{array}$ & Adverse Events & Asthma Approval & $\begin{array}{l}\text { Current } \\
\text { Clinical Trial } \\
\text { Phase }\end{array}$ & Findings & $\begin{array}{l}\text { Other } \\
\text { Populations } \\
\text { Investigated }\end{array}$ & $\begin{array}{l}\text { Ongoing Clinical } \\
\text { Trials }\end{array}$ \\
\hline \multirow{3}{*}{$\begin{array}{l}\text { Anti-IL-13: } \\
\text { Binds to IL-13 } \\
\text { cytokine at the } \\
\text { binding site of the } \\
\text { IL-13R } \alpha \text { receptors, } \\
\text { preventing } \\
\text { binding to } \\
\text { IL-13R } \alpha 1 \text { and } \alpha 2 \text {. } \\
\text { Lebrikizumab also } \\
\text { blocks binding to } \\
\text { IL- } 4 R \alpha \text {. }\end{array}$} & Anrukinzumab & $\begin{array}{l}\text { IV infusion every } \\
2 \text { weeks }\end{array}$ & $\begin{array}{l}\text { No safety concerns } \\
\text { in Phase } 2 \text { studies }\end{array}$ & $\mathrm{N} / \mathrm{A}$ & - & $\mathrm{N} / \mathrm{A}$ & $\begin{array}{l}\text { Mild } \\
\text { AAs- } \downarrow \text { allergen } \\
\text { induced FEV1 at } \\
\text { Day } 14 \text { but not } \\
\text { Day } 35 \text {. } \\
\text { Ulcerative Colitis }\end{array}$ & NCT01284062 \\
\hline & Lebrikizumab & $\begin{array}{l}\text { Fixed dose- } \\
250 \text { mg SC every } \\
4 \text { weeks }\end{array}$ & $\begin{array}{l}\text { No safety concerns } \\
\text { in a Phase } 3 \text { study }\end{array}$ & $\mathrm{N} / \mathrm{A}$ & - & $\begin{array}{l}\text { Inconsistent effect on } \\
\text { AER across } 2 \text { phase } \\
3 \text { clinical trials } \\
\uparrow \text { FEV1 } \\
\downarrow \text { Feno }\end{array}$ & Atopic Dermatitis & $\begin{array}{l}\text { NCT04250350 } \\
\text { NCT04392154 }\end{array}$ \\
\hline & RPC4046 & SC injection & $\begin{array}{l}\text { Unknown in } \\
\text { asthma population }\end{array}$ & $\mathrm{N} / \mathrm{A}$ & 1 & $\mathrm{~N} / \mathrm{A}$ & EoE & $\begin{array}{l}\text { NCT02098473 } \\
\text { NCT04753697 } \\
\end{array}$ \\
\hline \multirow{2}{*}{$\begin{array}{l}\text { Anti-IL4/IL-13: } \\
\text { Blocks the IL-4R } \alpha \\
\text { where it binds to } \\
\text { IL-4 and IL-13, } \\
\text { blocking IL-4 and } \\
\text { IL-13 signalling }\end{array}$} & Dupilumab & $\begin{array}{l}\text { Age and weight } \\
\text { based-200 or } \\
300 \text { mg SC every } \\
2 \text { weeks }\end{array}$ & $\begin{array}{l}\text { Rarely causes } \\
\text { hypersensitivity } \\
\text { reactions } \\
\text { Increased risk of } \\
\text { injection site } \\
\text { reactions }\end{array}$ & $\begin{array}{l}\text { Uncontrolled } \\
\text { severe } \\
\text { eosinophilic } \\
\text { asthma aged } \\
\geq 12 \text { years }\end{array}$ & - & $\begin{array}{l}\downarrow \text { Exacerbations } \\
\sim 50-60 \% \\
\downarrow \text { OCS use } \\
\text { Facilitates OCS weaning } \\
\uparrow \text { FEV1 }\end{array}$ & $\begin{array}{l}\text { Peanut Allergy } \\
\text { CRSsNP } \\
\text { EoE } \\
\text { Aspirin } \\
\text { Intolerance }\end{array}$ & $\begin{array}{l}\text { NCT03793608 } \\
\text { NCT04362501 } \\
\text { NCT03633617 } \\
\text { NCT04442256 }\end{array}$ \\
\hline & Pascolizumab & $\begin{array}{l}\text { Monthly IV } \\
\text { infusion }\end{array}$ & Unknown & $\mathrm{N} / \mathrm{A}$ & - & $\begin{array}{l}\text { A Phase } 2 \text { pilot study in } \\
\text { symptomatic steroid } \\
\text { naïve asthma failed to } \\
\text { show efficacy. }\end{array}$ & $\begin{array}{l}\text { Further } \\
\text { development } \\
\text { terminated }\end{array}$ & NCT00024544 \\
\hline
\end{tabular}


Table 1. Cont

\begin{tabular}{|c|c|c|c|c|c|c|c|c|}
\hline $\begin{array}{l}\text { Mechanism of } \\
\text { Action }\end{array}$ & Name & $\begin{array}{l}\text { Dosing and } \\
\text { Route }\end{array}$ & Adverse Events & Asthma Approval & $\begin{array}{l}\text { Current } \\
\text { Clinical Trial } \\
\text { Phase }\end{array}$ & Findings & $\begin{array}{l}\text { Other } \\
\text { Populations } \\
\text { Investigated }\end{array}$ & $\begin{array}{l}\text { Ongoing Clinical } \\
\text { Trials }\end{array}$ \\
\hline $\begin{array}{l}\text { Anti-IL4/IL-13: } \\
\text { Blocks the IL-4R } \alpha \\
\text { where it binds to } \\
\text { IL-4 and IL-13, } \\
\text { blocking IL-4 and } \\
\text { IL-13 signalling }\end{array}$ & Pitrakinra & Inhalation or SC & $\begin{array}{l}\text { No safety concerns } \\
\text { in a Phase } 2 \text { study }\end{array}$ & $\mathrm{N} / \mathrm{A}$ & - & $\begin{array}{l}\text { A Phase } 2 b \text { study found } \\
\text { no significant difference } \\
\text { in AER over placebo at } \\
\text { any dose. }\end{array}$ & $\begin{array}{l}\text { Further } \\
\text { development } \\
\text { terminated }\end{array}$ & NCT00801853 \\
\hline \multirow{2}{*}{$\begin{array}{l}\text { Anti-IL-33: } \\
\text { Monoclonal IgG } \\
\text { MAb that potently } \\
\text { and specifically } \\
\text { bind IL-33 }\end{array}$} & MEDI3506 & SC or IV & Unknown & $\mathrm{N} / \mathrm{A}$ & 2 & Trial currently recruiting & $\begin{array}{l}\text { COPD } \\
\text { Atopic Dermatitis } \\
\text { Diabetic Kidney } \\
\text { Disease }\end{array}$ & $\begin{array}{l}\text { NCT04570657 } \\
\text { NCT04631016 } \\
\text { NCT04212169 } \\
\text { NCT04170543 }\end{array}$ \\
\hline & REGN3500 & SC every 2 weeks & $\begin{array}{l}\text { No safety concerns } \\
\text { in a Phase } 2 \text { study }\end{array}$ & $\mathrm{N} / \mathrm{A}$ & 2 & $\begin{array}{l}\downarrow \text { LOAC compared to } \\
\text { placebo, however } \\
\text { dupilumab had a greater } \\
\text { effect }\end{array}$ & COPD & $\begin{array}{l}\text { NCT04701983 } \\
\text { NCT04751487 }\end{array}$ \\
\hline $\begin{array}{l}\text { Anti-ST2: } \\
\text { MAb binds to ST2, } \\
\text { the subunit of } \\
\text { IL-33 receptor }\end{array}$ & Astegolimab & SC every 4 weeks & Unknown & $\mathrm{N} / \mathrm{A}$ & $2 b$ & Results awaited & $\begin{array}{l}\text { Atopic Dermatitis } \\
\text { COPD } \\
\text { Covid-19 }\end{array}$ & $\begin{array}{l}\text { NCT03747575 } \\
\text { NCT03615040 } \\
\text { NCT04386616 } \\
\text { NCT02918019 }\end{array}$ \\
\hline \multirow{2}{*}{$\begin{array}{l}\text { Anti-TSLP: } \\
\text { Monoclonal } \\
\text { antibody binds to } \\
\text { TSLP preventing } \\
\text { its interaction with } \\
\text { its receptor }\end{array}$} & CSJ117 & $\begin{array}{l}\text { Inhaled TSLP } \\
\text { antibody fragment }\end{array}$ & Unknown & $\mathrm{N} / \mathrm{A}$ & 2 & Trial currently recruiting & $\begin{array}{l}\text { Mild } \\
\text { AAs- } \downarrow \text { allergen } \\
\text { induced responses }\end{array}$ & NCT04410523 \\
\hline & Tezepelumab & $\begin{array}{l}\text { Fixed dose- } \\
210 \text { mg every } \\
4 \text { weeks }\end{array}$ & $\begin{array}{l}\text { Similar safety } \\
\text { finding between } \\
\text { tezepelumab and } \\
\text { placebo * }\end{array}$ & $\mathrm{N} / \mathrm{A}$ & 3 & $\begin{array}{l}\downarrow \text { Exacerbations * } \\
\uparrow \text { FEV1 * }\end{array}$ & $\begin{array}{l}\text { COPD } \\
\text { Severe Steroid } \\
\text { Dependent } \\
\text { Asthma }\end{array}$ & $\begin{array}{l}\text { NCT04039113 } \\
\text { NCT03406078 }\end{array}$ \\
\hline
\end{tabular}


Table 1. Cont.

\begin{tabular}{|c|c|c|c|c|c|c|c|c|}
\hline $\begin{array}{l}\text { Mechanism of } \\
\text { Action }\end{array}$ & Name & $\begin{array}{l}\text { Dosing and } \\
\text { Route }\end{array}$ & Adverse Events & Asthma Approval & $\begin{array}{l}\text { Current } \\
\text { Clinical Trial } \\
\text { Phase }\end{array}$ & Findings & $\begin{array}{l}\text { Other } \\
\text { Populations } \\
\text { Investigated }\end{array}$ & $\begin{array}{l}\text { Ongoing Clinical } \\
\text { Trials }\end{array}$ \\
\hline \multirow{5}{*}{$\begin{array}{l}\text { CRTh2: } \\
\text { DP2 Antagonist }\end{array}$} & AZD1981 & $\begin{array}{l}\text { Once or twice } \\
\text { daily tablet }\end{array}$ & $\begin{array}{l}\text { No safety concerns } \\
\text { in Phase } 2 \text { studies }\end{array}$ & $\mathrm{N} / \mathrm{A}$ & - & $\begin{array}{l}\text { No change in FEV1 or } \\
\text { asthma control }\end{array}$ & COPD & NCT00690482 \\
\hline & BI674800 & $\begin{array}{l}\text { Inhaled twice } \\
\text { daily }\end{array}$ & $\begin{array}{l}\text { No safety concerns } \\
\text { in Phase } 2 \text { studies }\end{array}$ & $\mathrm{N} / \mathrm{A}$ & - & $\begin{array}{l}\text { Inconsistent effect on } \\
\text { FEV1 and ACQ across } \\
2 \text { phase } 2 \text { clinical trials }\end{array}$ & $\begin{array}{l}\text { Further } \\
\text { development } \\
\text { terminated }\end{array}$ & $\begin{array}{l}\text { NCT01090024 } \\
\text { NCT01092143 }\end{array}$ \\
\hline & Fevipiprant & Once daily tablet & $\begin{array}{l}\text { No safety concerns } \\
\text { in Phase } 3 \text { studies }\end{array}$ & $\mathrm{N} / \mathrm{A}$ & 3 & $\begin{array}{l}\text { AER-22\% reduction in } \\
\text { overall asthma } \\
\text { population, } 23 \% \text { in } \\
\text { eosinophil-high } \\
\text { population }\end{array}$ & $\begin{array}{l}\text { COPD- } \\
\text { terminated }\end{array}$ & NCT03810183 \\
\hline & GB001 & Once daily tablet & Unknown & $\mathrm{N} / \mathrm{A}$ & $2 b$ & $\begin{array}{l}\text { Asthma worsening or } \\
\text { AER-no benefit }\end{array}$ & $\begin{array}{l}\text { CRSsNP } \\
\text { CRSwNP }\end{array}$ & $\begin{array}{l}\text { NCT03683576 } \\
\text { NCT03956862 }\end{array}$ \\
\hline & Timapiprant & Once daily tablet & $\begin{array}{l}\text { No safety concerns } \\
\text { in Phase } 2 \text { studies }\end{array}$ & & 2 & $\begin{array}{l}\text { No significant difference } \\
\text { in sputum eosinophils or } \\
\text { FEV1 }\end{array}$ & $\begin{array}{l}\text { Moderate asthma } \\
-\downarrow \text { sputum } \\
\text { eosinophils, } \uparrow \text { FEV1 } \\
\text { Atopic dermatitis }\end{array}$ & NCT02660489 \\
\hline $\begin{array}{l}\text { GATA-3 } \\
\text { DNAzyme: } \\
\text { Specifically, and } \\
\text { selectively targets } \\
\text { GATA3 }\end{array}$ & SB010 & $\begin{array}{l}\text { Inhalation once } \\
\text { daily }\end{array}$ & $\begin{array}{l}\text { No safety concerns } \\
\text { in a small Phase } 2 a \\
\text { study }\end{array}$ & $\mathrm{N} / \mathrm{A}$ & $2 a$ & $\mathrm{~N} / \mathrm{A}$ & $\begin{array}{l}\text { Mild } \\
\text { AAs }-\downarrow \text { allergen } \\
\text { induced responses } \\
\text { COPD }\end{array}$ & \\
\hline \multirow{2}{*}{$\begin{array}{l}\beta_{\mathrm{c}} \text { receptor: } \\
\text { blocking } \\
\text { binding/synthesis } \\
\text { of common } \beta_{\mathrm{c}} \\
\text { receptor -of IL-3, } \\
\text { GM-CSGF and IL-5 }\end{array}$} & CSL311 & $\begin{array}{l}\text { Dose ascending } \\
\text { study ongoing }\end{array}$ & Unknown & $\mathrm{N} / \mathrm{A}$ & 1 & $\mathrm{~N} / \mathrm{A}$ & Mild Asthma & NCT04082754 \\
\hline & TPI ASM8 & $\begin{array}{l}\text { Once daily } \\
\text { inhalation }\end{array}$ & $\begin{array}{l}\text { No safety concerns } \\
\text { in a small Phase } 2 \\
\text { studies }\end{array}$ & $\mathrm{N} / \mathrm{A}$ & $2 b$ & $\begin{array}{l}\text { Attenuation of } \\
\text { allergen-induced late } \\
\text { asthmatic response }\end{array}$ & $\begin{array}{l}\text { Further } \\
\text { development } \\
\text { terminated }\end{array}$ & $\begin{array}{l}\text { NCT01158898 } \\
\text { NCT00550797 } \\
\text { NCT00822861 } \\
\text { NCT00402948 }\end{array}$ \\
\hline
\end{tabular}


Table 1. Cont.

\begin{tabular}{|c|c|c|c|c|c|c|c|c|}
\hline $\begin{array}{l}\text { Mechanism of } \\
\text { Action }\end{array}$ & Name & $\begin{array}{l}\text { Dosing and } \\
\text { Route }\end{array}$ & Adverse Events & Asthma Approval & $\begin{array}{l}\text { Current } \\
\text { Clinical Trial } \\
\text { Phase }\end{array}$ & Findings & $\begin{array}{l}\text { Other } \\
\text { Populations } \\
\text { Investigated }\end{array}$ & $\begin{array}{l}\text { Ongoing Clinical } \\
\text { Trials }\end{array}$ \\
\hline $\begin{array}{l}\text { Anti-Siglec 8: } \\
\text { MAb binds to } \\
\text { Siglec-8 inducing } \\
\text { apoptosis of } \\
\text { eosinophils }\end{array}$ & Lirentelimab & $\begin{array}{l}\text { Monthly IV } \\
\text { infusion }\end{array}$ & Unknown & $\mathrm{N} / \mathrm{A}$ & - & - & $\begin{array}{l}\text { EoE } \\
\text { Chronic Urticaria }\end{array}$ & $\begin{array}{l}\text { NCT04620811 } \\
\text { NCT04322708 }\end{array}$ \\
\hline $\begin{array}{l}\text { Decreases } \\
\text { eosinophil } \\
\text { maturation }\end{array}$ & $\begin{array}{l}\text { Dexpramipex- } \\
\text { ole }\end{array}$ & Once daily tablet & $\begin{array}{l}\text { Increased risk of } \\
\text { neutropenia }\end{array}$ & $\mathrm{N} / \mathrm{A}$ & 2 & Trial currently recruiting & $\begin{array}{l}\text { CRSwNP } \\
\text { Amyotrophic } \\
\text { lateral sclerosis }\end{array}$ & NCT04046939 \\
\hline JAK inhibitor & AZD0449 & Inhaled therapy & Unknown & $\mathrm{N} / \mathrm{A}$ & 1 & $\mathrm{~N} / \mathrm{A}$ & $\begin{array}{l}\text { Mild allergic } \\
\text { asthma }\end{array}$ & NCT03766399 \\
\hline $\begin{array}{l}\text { Anti-CD4 MAb } \\
\text { that induces Treg } \\
\text { activation }\end{array}$ & Tregalizumab & SC injection & Unknown & $\mathrm{N} / \mathrm{A}$ & 2 & $\mathrm{~N} / \mathrm{A}$ & $\begin{array}{l}\text { Mild allergic } \\
\text { asthma } \\
\text { Rheumatoid } \\
\text { arthritis }\end{array}$ & NCT04673591 \\
\hline
\end{tabular}

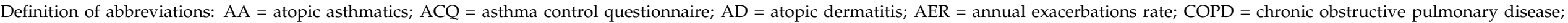

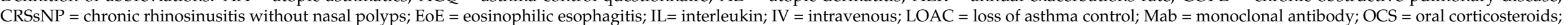

$\mathrm{SC}=$ subcutaneous. * - Based on one phase 3 trial result to date. 


\section{Glucocorticosteroids}

Glucocorticosteroids (GCs) are the most common and effective anti-inflammatory drugs used for the treatment of airway diseases, including asthma. The actions of glucocorticoids are mediated through glucocorticoid receptors (GR) that are expressed throughout the body. Upon activation of GR receptors through direct binding to DNA response elements and/or physical association with other transcription factors, the transcription of genes is either induced or repressed. Heterogeneity in glucocorticoid sensitivity and biological responses exists across tissues, mainly due to a diverse collection of receptor isoforms [5]. As such, the mechanism of action of GR agonists in asthma is nonspecific and impacts a wide variety of cells within the airways to suppress airway inflammation, prevent the recruitment of inflammatory cells to the airways, and indirectly promote the relaxation of smooth muscles [6-8].

Essential actions of inhaled glucocorticosteroids (ICSs) for the treatment of eosinophilic asthma include the prevention of eosinophil recruitment from the bone marrow and migration into the airways, as well as suppressing the expression of eosinophil survival factors and inducing eosinophil apoptosis [9]. GCs suppress eosinophil maturation by tempering the production and/or release of IL-3, IL-5, GM-CSF, and other eosinophil factors from cells within the bone marrow. Eosinophil proliferation and maturation are indirectly blocked through the suppression of cytokine release from accessory cells [10]. Glucocorticoids are reported to block the upregulation of specific adhesion molecules such as ICAM-1 and CD18 on eosinophils [11,12]. Certain cytokines, especially IL3, IL-5, GMCSF, and IFN- $\gamma$, prolong eosinophils' survival; however, when exposed to glucocorticoids, eosinophils undergo apoptosis, even in the presence of these cytokines [13-15]. Aside from eosinophils, GCs are proven to have broader impacts on other components of the immune system, leading to reduced manifestation in asthmatic patients. GCs inhibit lymphocyte activation and inflammatory mediator expression and induce lymphocyte apoptosis, actively reducing total blood lymphocyte numbers in asthmatics [16]. GCs have profound effects on the functionality, terminal differentiation, and activation status of macrophages and monocytes in asthma, reducing the expression of macrophage-derived proinflammatory cytokines and chemokines [17]. ICS treatment also reduces peripheral blood levels of monocytes and low-affinity IgE receptor expression [18]. Dendritic cells (DC) can be regulated by ICS through CCR7 expression, hampering DC migration to local lymphoid collections [19]. Finally, GCs suppress the release of Th1 and Th2 polarizing cytokines [20,21].

In contrast to the suppression of most innate immune-inflammatory responses in the airways, GCs seem to have little effect on neutrophil production and survival [22], in addition to macrophage phagocytosis and epithelial cell survival, and have been shown to increase the expression of Toll-like receptors, complement, pentraxins, collectins, SAA, and other host defense genes $[23,24]$. Historically, routine use of ICS to prevent airway inflammation in combination with rescue relievers such as $\beta_{2}$ agonists to relax smoothmuscle contractions are the most successful treatment for controlling asthma symptoms, reducing exacerbation, increasing lung function, and overall improving asthma control and quality of life. However, a small subset of asthmatic patients responds poorly to GC treatment, which is associated with neutrophilic airway inflammation [25]. While eosinophilic inflammation is known to be associated with better disease outcomes with ICS therapy, recent studies have shown that severe asthmatics with late-onset eosinophilic phenotype tend to have persistent airway inflammation even after GC therapies [26-30]. New and more specific GR agonists are being developed for more specific regulation of genes known to drive asthma [31].

\section{Targeting T2 Cytokines}

3.1. The IL-3/5/GM-CSF Axis

Growth factors IL-3, IL-5, and GM-CSF together are essential for inducing eosinophil differentiation from CD34+ pluripotent hematopoietic stem cells (HSCs), which are bone 
marrow progenitor cells [32]. These pleiotropic regulators are also critical for eosinophil survival, migration, and activation [33-35], to maintain steady-state hematopoiesis and regulation of inflammation in response to triggers such as pathogens, autoimmune disease, and cancer. From the HSCs, common myeloid progenitors differentiate into granulocytes/macrophage progenitors (GMPs), megakaryocyte/erythrocyte progenitors (MEPs) or CD34 + IL-5R $\alpha$ + eosinophil lineage-committed progenitors (EoPs) [36]. IL-3 and GMCSF are crucial in the early-stage differentiation of eosinophil progenitors from CD34+ cells, while IL-5 is required for their final maturation [37,38]. Eosinophils in immature states may concurrently develop locally within tissues or sites of infections via in situ hematopoiesis [39]. Lineage-committed eosinophil precursors, CD34 + /IL-5R $\alpha+$ precursor cells, are found at significantly higher concentrations in peripheral blood and bronchial biopsies of atopic asthmatics as compared to atopic and nonatopic nonasthmatic controls [37,40]. Eosinophil progenitors from the blood of patients with severe eosinophilic asthma have exaggerated clonogenic responses to IL-5 in vitro [34].

Despite eosinophils persisting at relatively low levels in the bloodstream, accounting for approximately $5 \%$ of the total white blood cell count in asthma [2], eosinophil counts increase drastically in the asthmatic airways after bronchoprovocation [3], and are found at high levels in airways of most patients with chronic asthma [4]. IL-3, IL-5, and GM-CSF contribute to eosinophil survival in tissue by delaying eosinophil apoptosis [41-43], as well as inducing eosinophil activation through degranulation [44-47]. Once eosinophils infiltrate a site of inflammation, stored mediators including toxic granule proteins, cytokines, chemokines, and growth factors are released during eosinophil degranulation [48].

IL-3, IL-5, and GM-CSF have heterodimeric receptors composed of a common $\beta$ receptor chain $(\beta c)$ and an individual $\alpha$ chain. These cytokines bind with low affinity (nanomolar) to their respective $\alpha$-chain, and recruitment of the $\beta$-chain results in a conformation change to a high-affinity (picomolar) binding complex [49]. The IL-5R $\alpha$ expression is typically limited to eosinophils and basophils, making it an ideal therapeutic target to reduce eosinophilia in allergic diseases (Figure 1).

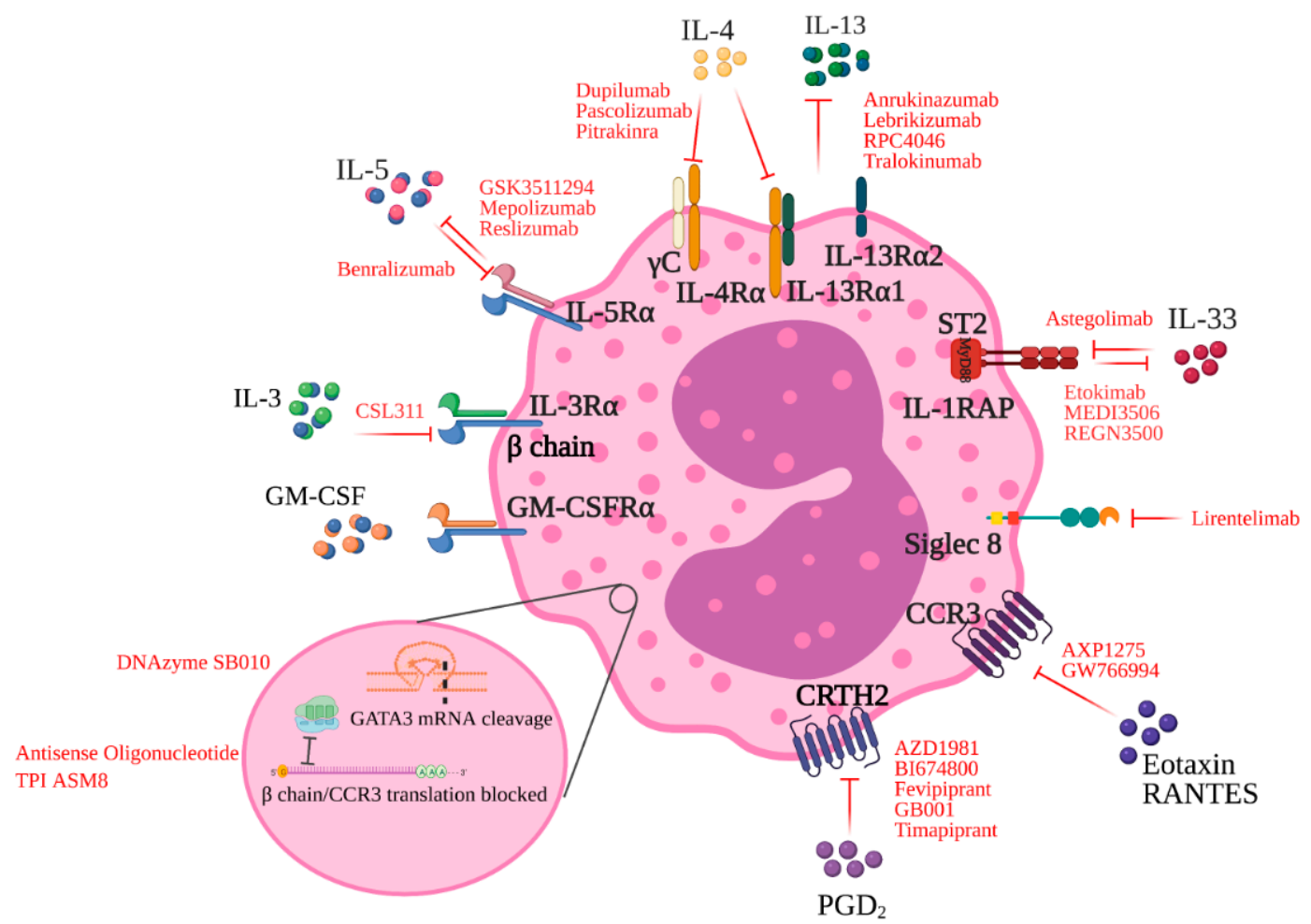

Figure 1. Eosinophil-targeted therapies and their ligands. 
The first class of eosinophil-targeted biological treatments, mepolizumab and reslizumab anti-IL-5 antibodies, aimed to reduce the circulating IL-5 cytokine levels and inhibit its receptor association through configural changes to the cytokine, respectively. Mepolizumab is a humanized monoclonal $N$-glycosylated $\operatorname{IgG} 1 / \mathrm{k}$ antibody that binds to the $\alpha$-chain of circulating IL-5, preventing its association with the $\alpha$ subunit of the IL- 5 receptors. Reslizumab is an IgG4/k humanized monoclonal antibody blocking circulating IL-5, preventing it from binding to eosinophil receptors [50]. In phase 3 clinical trials, mepolizumab (DREAM, MENSA, and SIRIUS) [51-53] and reslizumab (2 BREATH studies) [54] showed clinically significant reductions in exacerbations by approximately half in patients with severe eosinophilic asthma on the standard of care (at least medium-dose inhaled corticosteroids) with a poorly controlled disease (either two or more exacerbations in the preceding year of Asthma Control Questionnaire 1.5 or more). Both anti-IL-5 treatments produced small yet statistically significant improvements in mean prebronchodilator forced expiratory flow in one second $\left(\mathrm{FEV}_{1}\right)$. Mepolizumab and reslizumab were shown to have statistically significant effects at lower sputum eosinophil levels, yet had relatively smaller success at reducing blood eosinophil levels.

Benralizumab (IgG1/k) takes a unique approach by directly binding the $\alpha$ subunit of the IL-5 receptor-bearing cells such as eosinophils and basophils, thereby hindering eosinophilopoiesis, as well as eosinophil maturation and survival [50,55]. In addition, having a high affinity to human FcyRIII $\alpha$, benralizumab induces apoptosis through antibodydependent cell-mediated cytotoxicity (ADCC), whereby natural killer cells target and deplete IL-5 receptor alpha-bearing cells [46]. This approach avoids autoimmune-mediated worsening of asthma, which has previously been reported with low dose anti-IL-5 therapy $[56,57]$. Phase 3 clinical studies (SIROCCO, CALIMA, ZONDA, BISE) verified the use of benralizumab for severe, uncontrollable, high eosinophil blood count patients. Exacerbation rates were significantly reduced by as much as 70\% (ZONDA). Statistically significant increases in $\mathrm{FEV}_{1}$ were observed, as well as a $75 \%$ reduction in the oral glucocorticoid dose required by patients after treatment ceased (ZONDA) [58-61]. Blood eosinophil counts were reduced to below detection levels throughout treatment, and patients with blood eosinophil counts of $>300$ cells $/ \mathrm{mL}$ responded better than patients with blood eosinophil counts of $<300$ cells $/ \mathrm{mL}$. Although studies have suggested benralizumab as a promising biologic for asthma exacerbations, the clinical efficacy of benralizumab as compared to other IL-5 targeted therapies has not been established. However, Busse et al. and colleagues have reported that mepolizumab might be the better option compared to other anti-IL-5 antibodies. By indirect treatment comparison method and comparing the baseline eosinophil counts between patients receiving benralizumab, mepolizumab, and reslizumab, mepolizumab significantly improves the exacerbations in asthmatic patients [62]. Contrary to what was reported by Busse et al., Bourdin et al. reported similar efficacy for benralizumab and mepolizumab [63]. These conflicting results can only be addressed by direct comparisons of various therapies.

Although recent studies of anti-IL-5 therapies have led to a reduction in exacerbations and improvement of several asthma-control measures in a subpopulation of patients displaying severe eosinophilic asthma, there are other approaches for regulating eosinophils. Some therapies have been developed to target the common $\beta c(\beta c, \beta c R, C D 131, C S F 2 R B)$, which could effectively inhibit the activity of all three $\beta c$-signaling cytokines and affect the functionality of the hematopoietic cells they regulate. Studies of $\beta c$ - and IL-3-specific $\beta$ homodimer $\left(\beta_{\mathrm{IL}-3}\right)$-deficient mouse models of allergic inflammation $\left(\beta \mathrm{c}^{-/-}\right.$and $\beta_{\mathrm{IL}-3}{ }^{-/}$ designated $\beta \mathrm{c}^{-/-}$mice) demonstrated that signaling through $\beta c$ by IL-3, IL-5, and GMCSF is critical for the development and functionality of immune cells in the inflammatory response [64].

CSL311 is a novel IgG4/k human monoclonal antibody that binds to a unique epitope specific to the cytokine-binding site of the human $\beta$ common $(\beta c, \beta c R, C D 131, C S F 2 R B)$, aiming to specifically and effectively target inflammation mediated by IL-3, IL-5, and GM-CSF. CSL311 has a picomolar binding affinity for the human $\beta c$ receptor and, at 
therapeutic concentrations, is a highly potent antagonist of the united activities of IL-3, IL-5, and GM-CSF on eosinophil survival. CSL311 treatment in vitro has been shown to inhibit the survival of sputum-derived inflammatory cells collected from asthmatic patients undergoing allergen bronchoprovocation [65]. More recently, using a humanized mouse xenograft model, CSL311 was shown to inhibit human nasal polyp pathophysiology [66], further supporting a therapeutic role in eosinophilic disease. Currently, CSL311 is being evaluated for safety and tolerability in a phase 1 study conducted in patients with mild asthma (NCT04082754).

\subsection{IL-4 and IL-13 Blockade}

Other type 2 cytokines such as IL-4 and IL-13 are thought to contribute to eosinophilic airway disease through regulating the responses of lymphocytes, myeloid cells, and nonhematopoietic cells. Relating to asthma, IL-4 is known to induce the differentiation of naïve CD4 T cells into Th2 cells and drives the immunoglobulin (Ig) class switch to IgG1 and IgE in B cells [67]. IL-13 appears to have broader immunoregulatory and effector roles in allergic diseases such as bronchial asthma [68,69]. A variety of immune and nonimmune cells are known as IL-13 producers, including T cells, mast cells, basophils, dendritic cells, and keratinocytes [70-72]. IL-13 has been suggested to be a chemotactic factor, an activator, and a survival factor for eosinophils [73,74]. IL-13 promotes eosinophilic inflammation in part by upregulating the expression of eosinophil-attracting CCR3-binding chemokines. IL-13 also promotes leucocytes and resident airway cells to induce the CCR4-binding chemokines, which are increased in allergic asthma patients $[75,76]$. While eosinophils do not constitutively express IL-13, they have been shown to inducibly synthesize this cytokine upon stimulation with cytokines IL-5 and GM-CSF. As such, eosinophils in the T2 microenvironment, such as the asthmatic airway, could contribute to IL-13 production [77].

The cytokine-binding receptor chain for IL-4 is IL- $4 \mathrm{R} \alpha$, which is widely expressed. The IL-4/IL-4R $\alpha$-complex binds a secondary receptor chain, either IL-2R $\gamma_{\mathrm{c}}(\gamma \mathrm{c})$ or IL-13R $\alpha 1$. In contrast, the IL-13 receptor has two separate binding chains; namely, IL-13R $\alpha 1$ and IL$13 R \alpha 2$. Formation of a type I or a type II IL-4 receptor is determined after the IL-4/IL-4R $\alpha$ complex is formed, whereas binding of IL-13 upon either IL-13R $\alpha 1$ or IL-13R $\alpha 2$ determines which receptor IL-13 utilizes. Anti-IL-13 therapies have been developed to block the IL13 cytokine to interfere with binding to IL-13R $\alpha 1$ (IMA-026, tralokinumab), to interfere with binding to IL-4R $\alpha$ (IMA-638, lebrikizumab), or to block the IL-4R $\alpha$ where it binds to IL-4 and IL-13 (dupilumab), thus inhibiting IL-4 and IL-13 signaling (Figure 1). Allergen challenge studies in humans with mild allergic asthma have shown that interfering with IL-4R $\alpha$ binding [78-80], but not IL-13R $\alpha 1$ binding [78], attenuates allergen-induced late asthmatic response. In contrast, none of these anti-IL-13 monoclonal antibodies had any effect on eosinophil levels in blood or airways. A mechanistic study of lebrikizumab (IgG4) in moderate-to-severe uncontrolled asthma demonstrated no change in eosinophil numbers in the bronchial mucosa. However, lebrikizumab reduced subepithelial fibrosis, a feature of airway remodeling [81]. Tralukinumab (IgG4) and lebrikizumab asthma programs were both discontinued after failing in phase 2 and 3 trials, respectively [82-84]. Dupilumab (IgG4) met primary endpoints (occurrence of an asthma exacerbation, change in FEV1 in patients with baseline blood eosinophil counts of at least 300 eosinophils per $\mu \mathrm{L}$ ) for phase 3 studies in adults and children 12 years and older [85-88], showing elevated blood eosinophil levels after injection, which is presumably justified by the suppression of chemokine generation, leading to decreased recruitment of blood eosinophils into the lung tissue [89].

\section{Targeting Specific Receptors on Eosinophils \\ 4.1. CCR3 Blockade}

Other approaches for blocking eosinophil migration have targeted receptors of potent eosinophil chemokines. CCR3 is the cognate receptor for major human eosinophil chemoattractants, expressed by eosinophils [90] and important for their recruitment to the lung 
through its binding to eotaxin [91-93]. A number of other chemokines from the eotaxin family of proteins, including RANTES; MIP-1; and MCP-2, 3, and 4; many of which are elevated in asthma and correlate with disease severity, also bind to CCR3 (Figure 1). Although the eotaxin-CCR3 pathway is required for eosinophil trafficking, the CCR3 receptor is also present on other cells known to have effector functions in asthma, including basophils, mast cells, CD34 + cells, airway epithelial cells, and activated T cells [94]. With CCR3 having an association with many of the cells and chemokines involved in asthma and allergy, it is theorized that blockade of this receptor may have marked effects in eosinophilic diseases.

AXP1275 is a CCR3 receptor antagonist that has been evaluated for efficacy in the human allergen challenge model of asthma. This disease model had been widely used to examine efficacy of asthma drugs because (1) it mimics environmental allergen exposure; (2) it drives a cascade of inflammatory events, including IgE- and T2-mediated cellular inflammation; (3) it enhances well-defined features of asthma such as airway inflammation, bronchoconstriction and airway hyperresponsiveness that are responsive to anti-inflammatory therapy; and (4) experiments are conducted in steroid-naïve allergic mild asthmatics, which allows for investigation therapy to be assessed without confounding effects of background standard asthma therapy [3,95-97]. A two-week treatment regime of oral CCR3 antagonist followed by an inhaled allergen challenge in mild allergic asthmatics resulted in a trend, but no statistically significant reduction in allergen-induced airway eosinophils, with no change in physiological outcomes of allergen-induced bronchoconstriction [98]. It is possible that AXP1275 was not present at high enough concentrations to prevent allergen-induced cell migration, or that chemokines signaling through other receptors such as CCR2 and CCR5 helped to drive eosinophil migration postallergen challenge. There was, however, a significant improvement in airway hyperresponsiveness to methacholine. Interestingly these results were substantiated by another clinical trial using a different oral CCR3 antagonist in patients with asthma and eosinophilic bronchitis, showing that despite $90 \%$ receptor occupancy, there was no improvement in eosinophil counts in blood or airways, yet a modest and statistically significant improvement in methacholine PC20 [99]. These studies raise questions about the role of CCR3 in airway eosinophilia, and suggest CCR3-mediated mechanisms could be a factor in airway hyperresponsiveness of patients with asthma.

\subsection{CCR3 and Common $\beta$-Chain Blockade}

With considerable redundancy in receptors and chemokines involved in eosinophil recruitment, control of eosinophil levels may be more effective using a multifaceted approach that simultaneously blocks more than one mechanistic pathway. TPI ASM8 was developed as a drug composed of two modified phosphorothioate antisense oligonucleotides: TOP004, directed against the human common $\beta$ c of IL-3, IL-5, and GM-CSF receptors; and TOP005, directed against human CCR3 (Figure 1). Phosphorothioate oligodeoxynucleotides (ODNs) were designed to impart resistance to destructive cell nucleases, thereby maintaining structural integrity inside cells while inhibiting gene expression through low-stability formation duplexes with complementary RNA. TPI ASM8 was tested in the human allergen challenge model of asthma initially with a four-day treatment of $1500 \mathrm{mcg}$ once daily inhaled via nebulizer. The allergen-induced levels of $\beta c$ mRNA and CCR3 mRNA in sputum-derived cells were inhibited by TPI ASM8, demonstrating pharmacological and on-target effects. Compared with placebo, TPI ASM8 significantly reduced the early asthmatic bronchoconstrictor response, with a similar trend in the late asthmatic response. TPI ASM8 inhibited the allergen-induced sputum eosinophil influx by $46 \%$ and inhibited the increase in total cells by $63 \%$ after the allergen challenge [100]. A follow-up dose-response study with a four-day treatment of 1,2 , and $4 \mathrm{mg}$ twice daily and $8 \mathrm{mg}$ once daily, using the same allergen challenge model, demonstrated significant attenuation of all allergen-induced outcomes, early and late asthmatic responses, sputum eosinophils, airway eosinophil cationic protein (ECP) level, and methacholine $\mathrm{PC}_{20}$. [101] Studies on anti-CCR3 monoclonal antibodies in mouse models have also shown promising effects of this biologic on 
inhibiting eosinophilic inflammation in eosinophil-mediated diseases. Administering antiCCR3 antibody in mouse model of eosinophilic gastroenteritis significantly decreased GI eosinophilic inflammation and manifestations of the disease [102]. Similar results were also seen in the BAL and lung tissue of asthmatic mouse models treated with anti-CCR3 [103].

\subsection{CRTH2 Antagonism}

Chemoattractant receptor-homologous molecule (CRTH2) is a G-protein-coupled receptor selectively expressed by type $2 \mathrm{~T}$ lymphocytes, basophils, eosinophils, and ILC2s [104] (Figure 1). Prostaglandin D2 (PGD2) is secreted by activated mast cells and binds to the CRTH2 receptor, resulting in the release of IL-4, IL-5, and IL-13 from Th2 cells ILC2s [105]. Preclinical studies appeared promising, with a highly selective and potent CRTH2 antagonist reducing airway hyperresponsiveness; IL-4, IL-5, and IL-13 release; airway mucus production; and leukocyte infiltration [106]. This led to an interest in developing CRTH2 antagonists as a new asthma therapy. While CRTH2 antagonists are overall safe and well-tolerated in humans, results to date have shown mixed results. The oral CRTH2 antagonist OC000459 administered twice daily was tested in a placebocontrolled double-blind, parallel group study of steroid-free asthmatics with persistent symptoms [107]. The study trial results, excluding noncompliant subjects, did show a significant improvement in FEV1 of $9.2 \%$ for subjects on OC 000459 versus $1.8 \%$ on placebo $(p=0.037)$ and a reduction in mean sputum eosinophil counts from $2.1 \%$ to $0.7 \%(p=0.03)$ after OC000459 treatment. Similarly, the oral CRTH2 antagonist ARRY-502 in mild atopic asthmatics found a small but significant FEV1 improvement compared to placebo (3.9\%, $p=0.02)$, with improvements in ACQ-7, $\beta$-agonist use, and symptom-free days compared to placebo ( $p<0.001, p<0.001$, and $p=0.07$ respectively) [108]. Fevipiprant is an oral CRTH2 antagonist that showed promise in a single-center Phase 2 study of 61 moderateto-severe asthmatics with elevated sputum eosinophil counts at baseline [109]. This trial showed a significant reduction in sputum eosinophil levels after fevipiprant treatment (between-group difference 3.5-fold, $p \leq 0.01$ ), significant reductions in ACQ-7 score in the subgroup with poor control ( $p=0.046$, change in mean ACQ-7 $=-0.37$ ), and significant improvements in both postbronchodilator FEV1 and Asthma Quality of Life Score (AQLQ(S)) ( $p=0.021$, increased by $0.06 \mathrm{~L}$ and $p \leq 0.01$ increased by 0.27 points, respectively). Building on this trial, LUSTER-1 and LUSTER-2, two replicate Phase 3 randomized, double-blind, placebo-controlled, parallel-group trials of fevipiprant were completed, primarily aimed at reducing asthma exacerbations [110]. Both LUSTER trials were completed in subjects aged 12 years or over with uncontrolled asthma despite dual or triple asthma therapy, and subjects were randomized to once-daily fevipiprant $150 \mathrm{mg}$, fevipiprant $450 \mathrm{mg}$, or placebo on a 1:1:1, with two-thirds of patients having blood eosinophil counts of 250 cells / $\mu \mathrm{L}$ or higher. The primary efficacy endpoint of annualized rate of moderate-to-severe asthma exacerbations was not met in either trial, in either dose. Pooled analysis of both studies showed a $14 \%$ reduction in annual exacerbation rate in the high eosinophil population, with a $10 \%$ reduction in the overall population for the $150 \mathrm{mg}$ dose, and a $23 \%$ and $22 \%$ reduction, respectively, for the $450 \mathrm{mg}$ dose. Therefore, while the results are disappointing in the T2-high patient group, a $22 \%$ overall reduction in exacerbation rate at the higher dose suggests fevipiprant could be beneficial in the T2-low group.

\subsection{Regulation of Eosinophil Apoptosis}

Sialic-acid-binding immunoglobulin-like lectin (Siglec)-8 is a cell-surface inhibitory receptor expressed selectively on human eosinophils (Figure 1) and mast cells, and it is under investigation as a therapeutic target for the treatment of allergic and inflammatory diseases [111-113]. The binding of a monoclonal antibody to Siglec-8 (lirentelimab / AK002) has been shown to induce death of cytokine-primed eosinophils via antibody-dependent cellular cytotoxicity (ADCC) [112]. Experiments in airway cells from asthmatic patients have demonstrated that gene expression for Siglec- 8 increases in asthma, correlates with gene expression for eosinophils and mast cells, and is inversely correlated with measures 
of airflow obstruction. Furthermore, when airway cells were exposed to AK002 ex vivo, there was a reduction in the eosinophil population [114]. In clinical trials, the inhibitory activity mediated by AK002 has led to improvements in allergic diseases, including chronic spontaneous urticaria and eosinophilic gastritis $[115,116]$. For the treatment of asthma, targeting Siglec-8 appears to be a reasonable strategy to decrease sputum eosinophils, with the additional benefit of inhibiting lung mast cells. Ongoing trials are underway in patients with eosinophilic esophagitis (NCT04322708), but not in asthma at this time. Phase 2 clinical trials of AK200 (Lirentelimab) in patients with eosinophilic gastritis and eosinophilic duodenitis has presented anti-Siglec-8 antibody as a potential treatment for these patients [116]. Reports of this trial showed that the mean percentage change in gastrointestinal eosinophil count was $0.86 \%$, and the mean change of total symptom score was $-0.48 \%(p<0.001)$.

\section{Targeting Upstream Pathways of T2 Cytokines}

\subsection{GATA-3 DNAzyme}

Blocking pathways leading to the production of type 2 cytokines is another promising approach. The transcription factor GATA-3 promotes the development of naïve T cells into Th2 cells, and directly induces the production of Th2 cytokines by transactivation of the promoters for IL-5 and IL-13. GATA-3 also regulates other cell types involved in bronchial asthma, including mast cells, eosinophils, basophils, and epithelial cells [117-119]. The central role of GATA-3 in the underlying immune pathways for the development of inflammatory allergic responses, and its significantly increased expression in the airways of asthma patients [120-123], support GATA-3 as a novel target for therapeutic intervention in type-2-driven asthma (Figure 1). DNAzymes of 10-23 RNA-cleaving family are singlestranded catalytic DNA molecules containing two substrate-recognition domains that combine the specificity of DNA base pairing and a central catalytic domain that cleaves specific sequences in a target mRNA molecule [124]. It has been reported that GATA3-specific DNAzymes such as gd21 and hgd40 can significantly reduce GATA-3 mRNA expression and experimental asthma in vitro and in vivo $[117,118]$.

Furthermore, GATA-3 DNAzymes are reported to not have off-target effects, especially with regard to nonspecific activation of innate immune mechanisms such as those via TLR9, activation of the NFKB pathway, or release of proinflammatory cytokines [124]. Based on the overall positive results in animal models, the GATA-3-specific DNAzyme candidate hgd40 (also called SB010 for inhaled formulation) has been developed as a novel therapeutic approach for the treatment of allergic asthma [125-127], and has shown excellent safety and tolerability properties in preclinical and clinical phase I studies $[118,126]$. In a successful phase IIa study in the allergen challenge model in mild allergic asthmatics, SB010 significantly attenuated early and late asthmatic bronchoconstriction in association with a decrease in Th2-dependent biomarkers including sputum eosinophilia, sputum tryptase, and plasma IL-5 levels [128]. GATA-3 DNAzyme is being explored in other airway diseases such as chronic obstructive pulmonary disease (COPD), where inhalation of $10 \mathrm{mg}$ SB010 bid for 28 days in COPD patients significantly reduced sputum eosinophilia with a trend to lower IL-5 levels [129]. Collectively, these studies suggest GATA-3 DNAzymes could be an important new approach for the treatment of a variety of chronic inflammatory diseases.

\subsection{Anti-TSLP}

TSLP is produced by the epithelium following exposure to external stimuli such as viruses, bacteria, and allergens, and drives allergic inflammation through binding to the TSLP receptor (TSLPR) on numerous immune cells, including mast cells [130], dendritic cells [131], and eosinophils [132]. TSLP is present in increased levels within the bronchial mucosa of asthmatics compared to healthy controls [133], with TSLP expression increased within a subset of severe asthmatics despite high-dose corticosteroid therapies [134]. TSLPR deficiency in mice results in reduced ILC2 expression of IL-5, IL-13, and airway eosinophils. TSLP and IL-33 appear to work synergistically and enhance the expression of each other's 
receptors on ILC2s, resulting in increased allergic inflammation [135]. Blocking TSLP in the allergen challenge model in mild allergic asthma inhibited allergen-induced early and late asthmatic responses and eosinophilic inflammation $[97,136]$. These data suggest that the TSLP blockade inhibits the release of proinflammatory cytokines by immune cells, and may also help prevent asthma exacerbations and improve asthma control. Due to its activity early in the inflammation cascade, blockade of TSLP may be suitable for a broad population of patients with severe, uncontrolled asthma. Moreover, a recent study done by Kabata et al. has shown that high expression of TSLP is associated with corticosteroid resistance in patients with severe asthma. This study suggests that blockade of TSLP can improve corticosteroid resistance in severe asthmatics [137].

Tezepelumab is a first-in-class, fully human anti-TSLP monoclonal immunoglobulin G2 $\lambda$ that specifically binds to human TSLP and prevents interaction with its receptor [138]. The US Food and Drug Administration (FDA) has recently granted Breakthrough Therapy Designation for tezepelumab in patients with severe asthma, without an eosinophilic phenotype, who are receiving inhaled corticosteroids/long-acting beta2-agonists with or without oral corticosteroids and additional asthma controllers. The Breakthrough Therapy Designation is based on the tezepelumab Phase IIb PATHWAY data [139]. The trial showed annual asthma exacerbation rate reductions of $62 \%, 71 \%$, and $66 \%$ in the tezepelumab arms receiving either $70 \mathrm{mg}$ or $210 \mathrm{mg}$ every four weeks or $280 \mathrm{mg}$ every two weeks compared to placebo ( $p<0.001$ for all comparisons), respectively. These results were observed independent of baseline blood eosinophil count or other T2 inflammatory biomarkers. This trial also showed a significant reduction in the annual asthma exacerbation rate compared with placebo in a broad population of severe asthma patients irrespective of patient phenotype, including T2 biomarker status. Building on the PATHWAY Phase IIb trial, the PATHFINDER Phase III program was initiated in the fourth quarter of 2017 with two pivotal trials: NAVIGATOR [140] and SOURCE (unpublished). The NAVIGATOR was a Phase 3, multicenter, randomized, double-blind placebo-controlled trial of patients aged 12-80 years with severe uncontrolled asthma, randomized 1:1 to receive tezepelumab $210 \mathrm{mg}$ subcutaneously or placebo every 4 weeks for 52 weeks. The primary endpoint of annualized asthma exacerbation rate overall in the population showed a $56 \%$ reduction compared to placebo in the tezepelumab group $(p \leq 0.01)$, and by $70 \%, 41 \%$, and $39 \%$ in patients with baseline blood eosinophil counts of $\geq 300,<300$, and $<150$ cells $/ \mu \mathrm{L}$, respectively. Tezepelumab also significantly improved FEV1, Asthma Control Questionnaire-6 (ACQ-6) scores compared to placebo $(p \leq 0.01)$, with similar safety findings between tezepelumab and placebo. The tezepelumab program includes additional planned mechanistic and longterm safety trials, and appears to be a promising treatment for a broad asthma population. An inhaled TSLP antibody fragment, CSJ117, has also shown efficacy, and will be tested in a larger phase 2 clinical trial in patients with severe uncontrolled asthma (NCT04410523).

\subsection{Anti-IL-33}

IL-33 is an alarmin cytokine released by the airway epithelium following exposure to external stimuli such as viruses, bacteria, and allergens. IL-33 induces Th2 differentiation and the release of cytokines including IL-4, IL-5, and IL-13, and the activation of ILC2s, which rapidly release large quantities of IL-5 and IL-13 [141]. These cytokines promote the activation and survival of mast cells, eosinophils, basophils, and mediate innate type 2 immunity and allergic inflammation in the lungs. IL-33 levels in asthmatics compared to controls have been significantly higher within the peripheral blood, and IL-33 levels were negatively correlated to FEV1 and positively correlated to asthma severity [142]. This had led to an interest in anti-IL-33 biological agents as possible future therapies.

Early animal studies targeting IL-33 were encouraging, with a reduction in bronchoalveolar fluid eosinophilia and airway hyperresponsiveness to methacholine [143]. Phase 2 clinical studies have been disappointing to date. SAR440340 is a human IgG4P monoclonal antibody against IL-33 that was tested in a four-arm, randomized, doubleblind placebo-controlled trial, a 12-week proof-of-concept trial of SAR440340 monotherapy, 
dupilumab, and in combination with dupilumab, in uncontrolled moderate-to-severe asthmatics despite ICS/LABA therapy [144]. SAR440340 therapy was well tolerated, and treatment significantly reduced the proportion of loss of asthma control (LOAC) events compared to placebo, as well as improved FEV1 at 12 weeks. However, dupilumab alone had a greater improvement effect on both LOAC events and FEV1 improvement, with no incremental improvement with combination therapy. Therefore it is unlikely that SARS440340 will move into phase 3 clinical studies in asthma. Similarly, a phase 2, randomized, double-blind placebo-controlled trial of GSK3772847, an IL-33 receptor antagonist, was negative. The trial showed no statistical improvement in LOAC, with $67 \%$ of patients in the GSK3772847 arm suffering LOAC, compared to $81 \%$ in the placebo arm, and more subjects within the GSK3772847 group experienced a clinically significant asthma exacerbation (13\% in the GSK3772847 group vs. 7\% in the placebo group (NCT03207243)). Etokimab is another humanized IL-33 antibody that has completed a Phase 2a clinical trial, in 25 adult patients with severe eosinophilic asthma despite ICS/LABA therapy (blood eosinophils $\geq 300 / \mathrm{mL}$ ), randomized to receive either $300 \mathrm{mg}$ of etokimab or placebo [145]. The results showed improved FEV1 (11\% maximum reduction in FEV1 over placebo at day 64 ) and reduced blood eosinophil level (46\% maximum reduction in FEV1 over placebo at day 64); no further studies are planned. While anti-IL-33 antibodies have now largely been abandoned in asthma, trials are still ongoing in other allergic diseases, including peanut allergy and atopic dermatitis.

\subsection{Targeting ILC2s}

Group 2 innate lymphoid cells (ILC2s) are part of a family of cells that lack antigenspecific receptors and link the innate and adaptive immune responses in the pathogenesis of the allergic disease [146,147]. ILC2s are found within the airways, intestines, skin, and blood [148,149], with increased ILC2 numbers in the blood of patients with allergic diseases such as asthma [150], allergic rhinitis [151], and atopic dermatitis [152]. Accumulations of ILC2s have been reported at sites of eosinophilic inflammation: in acute lesional skin in atopic dermatitis; in the upper airways within diseased mucosa and polys in chronic rhinosinusitis $[153,154]$; in eosinophilic pleural effusions of primary spontaneous pneumothoraxes [155]; and most notably, in the lower airways, greater numbers of ILC2s are detected in the sputum of patients with severe asthma compared to mild asthma despite high-dose oral corticosteroid therapy [156]. Human ILC2 are typically defined as lineage ${ }^{-}$IL-7R $\alpha^{+} \mathrm{NKp} 44^{-} \mathrm{CD} 25^{+} \mathrm{CD} 161^{+} \mathrm{CRTH} 2^{+}$[148].

ILC2s are a significant source of T2 cytokines that drive allergic inflammation. In response to aeroallergens exposure [157], parasitic [158] or viral infection [159], the bronchial epithelium releases the cytokines IL-25 and IL-33, and thymic stromal lymphopoietin (TSLP), which results in ILC2 activation $[146,160]$. Once activated, ILC2 cells rapidly proliferate and produce Th2 cytokines IL-4, IL-5, IL-6, IL-9, and IL-13 in abundant amounts [161] in the absence of $\mathrm{CD} 4^{+} \mathrm{T}$ cells [141]. IL-4 secretion is needed for Th2 differentiation, B-cell proliferation, and mast-cell activation [162]. Human studies have found increases in activated ILC2s in asthmatics' airways 7 to $24 \mathrm{~h}$ after allergen inhalation challenge, with CD4 ${ }^{+}$ $\mathrm{T}$ cells increased in sputum at 24 to $48 \mathrm{~h}$ after the allergen challenge [157]. ILC2 activation and resultant Th2 cytokine release is now considered a key event in type 2 inflammatory diseases, with the production and release of IL-5 resulting in eosinophilia, IL-13 resulting in airway mucus production and remodeling, and IL-9 promoting goblet cell hyperplasia and mastocytosis [141,163-165]. This demonstrates that ILC2s are critical in developing allergic diseases. Targeting and depleting ILC2s could have a significant therapeutic value, as targeting upstream T2 inflammation may provide additional treatment options for noneosinophilic asthma patients.

\section{Conclusions}

Over the past decade, anti-IL-5 therapies have been carefully evaluated and are now widely accepted for the treatment of eosinophilic asthma. While anti-IL-5 treatment 
has been widely approved for treating eosinophilic asthma, attenuation of broad-range inflammatory and physiological changes after allergen challenge suggests that blocking CCR3, IL-3, and GM-CSF are also important targets for the management of allergic asthma. Recent research into the underlying pathophysiology of asthma, the contribution of other inflammatory cells, and an improved understanding of upstream mechanisms have led to development of other novel therapies. These asthma therapies have been directed against interleukin 4/interleukin 13, thymic stromal lymphopoietin, CRTH2 antagonists, and the IL-3/5/GM-CSF axis, and bring the possibility of improved asthma control for patients with severe asthma.

Author Contributions: All authors contributed to the drafting of this manuscript and approved the submission. All authors have read and agreed to the published version of the manuscript.

Funding: This research received no external funding.

Informed Consent Statement: Not applicable.

Conflicts of Interest: The authors declare no conflict of interest.

\section{References}

1. Schuijs, M.J.; Willart, M.A.; Hammad, H.; Lambrecht, B.N. Cytokine targets in airway inflammation. Curr. Opin. Pharmacol. 2013, 13, 351-361. [CrossRef] [PubMed]

2. Blumenreich, M.S. The White Blood Cell and Differential Count. In Clinical Methods: The History, Physical, and Laboratory Examinations; Walker, H.K., Hall, W.D., Hurst, J.W., Eds.; Butterworths: Boston, MA, USA, 1990.

3. Gauvreau, G.M.; Watson, R.M.; O’Byrne, P.M. Kinetics of allergen-induced airway eosinophilic cytokine production and airway inflammation. Am. J. Respir. Crit. Care Med. 1999, 160, 640-647. [CrossRef] [PubMed]

4. Chabra, R.; Gupta, M. Allergic and Environmental Induced Asthma; StatPearls Publishing LLC.: Treasure Island, FL, USA, 2020.

5. Ramamoorthy, S.; Cidlowski, J.A. Corticosteroids: Mechanisms of Action in Health and Disease. Rheum. Dis. Clin. N. Am. 2016, 42, 15-31. [CrossRef] [PubMed]

6. O'Byrne, P.; Fabbri, L.M.; Pavord, I.D.; Papi, A.; Petruzzelli, S.; Lange, P. Asthma progression and mortality: The role of inhaled corticosteroids. Eur. Respir. J. 2019, 54, 1900491. [CrossRef] [PubMed]

7. Rogliani, P.; Ritondo, B.L.; Puxeddu, E.; Pane, G.; Cazzola, M.; Calzetta, L. Experimental Glucocorticoid Receptor Agonists for the Treatment of Asthma: A Systematic Review. J. Exp. Pharmacol. 2020, 12, 233-254. [CrossRef] [PubMed]

8. Ingawale, D.K.; Mandlik, S.K. New insights into the novel anti-inflammatory mode of action of glucocorticoids. Immunopharmacol. Immunotoxicol. 2020, 42, 59-73. [CrossRef]

9. Giembycz, M.A.; Lindsay, M.A. Pharmacology of the eosinophil. Pharmacol. Rev. 1999, 51, 213-340.

10. Shalit, M.; Sekhsaria, S.; Malech, H.L. Modulation of growth and differentiation of eosinophils from human peripheral blood CD34+ cells by IL5 and other growth factors. Cell Immunol. 1995, 160, 50-57. [CrossRef]

11. Guida, L.; O'Hehir, R.E.; Hawrylowicz, C.M. Synergy between dexamethasone and interleukin-5 for the induction of major histocompatibility complex class II expression by human peripheral blood eosinophils. Blood 1994, 84, 2733-2740. [CrossRef]

12. Tomioka, K.; MacGlashan, D.W., Jr.; Lichtenstein, L.M.; Bochner, B.S.; Schleimer, R.P. GM-CSF regulates human eosinophil responses to F-Met peptide and platelet activating factor. J. Immunol. 1993, 151, 4989-4997.

13. Lamas, A.M.; Marcotte, G.V.; Schleimer, R.P. Human endothelial cells prolong eosinophil survival. Regulation by cytokines and glucocorticoids. J. Immunol. 1989, 142, 3978-3984.

14. Lamas, A.M.; Leon, O.G.; Schleimer, R.P. Glucocorticoids inhibit eosinophil responses to granulocyte-macrophage colonystimulating factor. J. Immunol. 1991, 147, 254-259. [PubMed]

15. Cox, G. Glucocorticoid treatment inhibits apoptosis in human neutrophils. Separation of survival and activation outcomes. J. Immunol. 1995, 154, 4719-4725. [PubMed]

16. Rhen, T.; Cidlowski, J.A. Antiinflammatory action of glucocorticoids-New mechanisms for old drugs. N. Engl. J. Med. 2005, 353, 1711-1723. [CrossRef] [PubMed]

17. Donnelly, L.E.; Barnes, P.J. Defective phagocytosis in airways disease. Chest 2012, 141, 1055-1062. [CrossRef] [PubMed]

18. Ishmael, F.T.; Fang, X.; Galdiero, M.R.; Atasoy, U.; Rigby, W.F.C.; Gorospe, M.; Cheadle, C.; Stellato, C. Role of the RNA-binding protein tristetraprolin in glucocorticoid-mediated gene regulation. J. Immunol. 2008, 180, 8342-8353. [CrossRef]

19. Lambrecht, B.N.; Hammad, H. Lung dendritic cells in respiratory viral infection and asthma: From protection to immunopathology. Annu. Rev. Immunol. 2012, 30, 243-270. [CrossRef]

20. Ito, K.; Yamamura, S.; Essilfie-Quaye, S.; Cosio, B.; Ito, M.; Barnes, P.J.; Adcock, I.M. Histone deacetylase 2-mediated deacetylation of the glucocorticoid receptor enables NF-kappaB suppression. J. Exp. Med. 2006, 203, 7-13. [CrossRef]

21. Umland, S.P.; Schleimer, R.P.; Johnston, S.L. Review of the molecular and cellular mechanisms of action of glucocorticoids for use in asthma. Pulm. Pharmacol. Ther. 2002, 15, 35-50. [CrossRef] [PubMed] 
22. Hallett, J.M.; Leitch, A.E.; Riley, N.A.; Duffin, R.; Haslett, C.; Rossi, A.G. Novel pharmacological strategies for driving inflammatory cell apoptosis and enhancing the resolution of inflammation. Trends Pharmacol. Sci. 2008, 29, 250-257. [CrossRef] [PubMed]

23. Schleimer, R.P. Glucocorticoids suppress inflammation but spare innate immune responses in airway epithelium. Proc. Am. Thorac. Soc. 2004, 1, 222-230. [CrossRef] [PubMed]

24. Zhang, N.; Truong-Tran, Q.A.; Tancowny, B.; Harris, K.E.; Schleimer, R.P. Glucocorticoids enhance or spare innate immunity: Effects in airway epithelium are mediated by CCAAT/enhancer binding proteins. J. Immunol. 2007, 179, 578-589. [CrossRef] [PubMed]

25. Wenzel, S.E.; Szefler, S.J.; Leung, D.Y.; Sloan, S.I.; Rex, M.D.; Martin, R.J. Bronchoscopic evaluation of severe asthma. Persistent inflammation associated with high dose glucocorticoids. Am. J. Respir. Crit. Care Med. 1997, 156 Pt 1, 737-743. [CrossRef]

26. Green, R.H.; Brightling, C.E.; McKenna, S.; Hargadon, B.; Parker, D.; Bradding, P.; Wardlaw, A.J.; Pavord, I.D. Asthma exacerbations and sputum eosinophil counts: A randomised controlled trial. Lancet 2002, 360, 1715-1721. [CrossRef]

27. Kupczyk, M.; Haque, S.; Middelveld, R.J.; Dahlén, B.; Dahlén, S.E. Phenotypic predictors of response to oral glucocorticosteroids in severe asthma. Respir. Med. 2013, 107, 1521-1530. [CrossRef] [PubMed]

28. Wenzel, S.E. Asthma phenotypes: The evolution from clinical to molecular approaches. Nat. Med. 2012, 18, 716-725. [CrossRef] [PubMed]

29. Chambers, E.S.; Nanzer, A.M.; Pfeffer, P.E.; Richards, D.F.; Timms, P.M.; Martineau, A.R.; Griffiths, C.J.; Corrigan, C.J.; Hawrylowicz, C.M. Distinct endotypes of steroid-resistant asthma characterized by IL-17A(high) and IFN- $\gamma$ (high) immunophenotypes: Potential benefits of calcitriol. J. Allergy Clin. Immunol. 2015, 136, 628-637.e4. [CrossRef] [PubMed]

30. Nabe, T. Steroid-Resistant Asthma and Neutrophils. Biol. Pharm. Bull. 2020, 43, 31-35. [CrossRef] [PubMed]

31. Gauvreau, G.M.; Boulet, L.-P.; Leigh, R.; Cockcroft, D.W.; Killian, K.J.; Davis, B.E.; Deschesnes, F.; Watson, R.M.; Swystun, V.; Mårdh, C.K.; et al. A nonsteroidal glucocorticoid receptor agonist inhibits allergen-induced late asthmatic responses. Am. J. Respir. Crit. Care Med. 2015, 191, 161-167. [CrossRef] [PubMed]

32. Liu, F.T.; Goodarzi, H.; Chen, H.Y. IgE, mast cells, and eosinophils in atopic dermatitis. Clin. Rev. Allergy Immunol. 2011, 41, 298-310. [CrossRef] [PubMed]

33. Lopez, A.F.; Williamson, D.J.; Gamble, J.R.; Begley, C.G.; Harlan, J.M.; Klebanoff, S.J.; Waltersdorph, A.; Wong, G.; Clark, S.C.; Vadas, M.A. Recombinant human granulocyte-macrophage colony-stimulating factor stimulates in vitro mature human neutrophil and eosinophil function, surface receptor expression, and survival. J. Clin. Investig. 1986, 78, 1220-1228. [CrossRef] [PubMed]

34. Lopez, A.F.; Sanderson, C.J.; Gamble, J.R.; Campbell, H.D.; Young, I.G.; Vadas, M.A. Recombinant human interleukin 5 is a selective activator of human eosinophil function. J. Exp. Med. 1988, 167, 219-224. [CrossRef] [PubMed]

35. Rothenberg, M.E.; Owen, W.F.; Jr Silberstein, D.S.; Woods, J.; Soberman, R.J.; Austen, K.F.; Stevens, R.L. Human eosinophils have prolonged survival, enhanced functional properties, and become hypodense when exposed to human interleukin 3. J. Clin. Investig. 1988, 81, 1986-1992. [CrossRef]

36. Mori, Y.; Iwasaki, H.; Kohno, K.; Yoshimoto, G.; Kikushige, Y.; Okeda, A.; Uike, N.; Niiro, H.; Takenaka, K.; Nagafuji, K.; et al. Identification of the human eosinophil lineage-committed progenitor: Revision of phenotypic definition of the human common myeloid progenitor. J. Exp. Med. 2009, 206, 183-193. [CrossRef] [PubMed]

37. Robinson, D.S.; Damia, R.; Zeibecoglou, K.; Molet, S.; North, J.; Yamada, T.; Barry Kay, A.; Hamid, Q. CD34(+)/interleukin5Ralpha messenger RNA+ cells in the bronchial mucosa in asthma: Potential airway eosinophil progenitors. Am. J. Respir. Cell Mol. Biol. 1999, 20, 9-13. [CrossRef]

38. Sehmi, R.; Baatjes, A.J.; Denburg, J.A. Hemopoietic progenitor cells and hemopoietic factors: Potential targets for treatment of allergic inflammatory diseases. Curr. Drug Targets Inflamm. Allergy 2003, 2, 271-278. [CrossRef]

39. Hui, C.C.; McNagny, K.M.; Denburg, J.A.; Siracusa, M.C. In situ hematopoiesis: A regulator of TH2 cytokine-mediated immunity and inflammation at mucosal surfaces. Mucosal. Immunol. 2015, 8, 701-711. [CrossRef]

40. Sehmi, R.; Howie, K.; Sutherland, D.R.; Schragge, W.; O’Byrne, P.M.; Denburg, J.A. Increased levels of CD34+ hemopoietic progenitor cells in atopic subjects. Am. J. Respir. Cell Mol. Biol. 1996, 15, 645-655. [CrossRef]

41. Shen, Z.J.; Malter, J.S. Determinants of eosinophil survival and apoptotic cell death. Apoptosis 2015, 20, 224-234. [CrossRef]

42. Esnault, S.; Kelly, E.A.; Shen, Z.J.; Johansson, M.W.; Malter, J.S.; Jarjour, N.N. IL-3 Maintains Activation of the p90S6K/RPS6 Pathway and Increases Translation in Human Eosinophils. J. Immunol. 2015, 195, 2529-2539. [CrossRef]

43. Tai, P.C.; Sun, L.; Spry, C.J. Effects of IL-5, granulocyte/macrophage colony-stimulating factor (GM-CSF) and IL-3 on the survival of human blood eosinophils in vitro. Clin. Exp. Immunol. 1991, 85, 312-316. [CrossRef] [PubMed]

44. Fujisawa, T.; Abu-Ghazaleh, R.; Kita, H.; Sanderson, C.J.; Gleich, G.J. Regulatory effect of cytokines on eosinophil degranulation. J. Immunol. 1990, 144, 642-646. [PubMed]

45. Horie, S.; Gleich, G.J.; Kita, H. Cytokines directly induce degranulation and superoxide production from human eosinophils. J. Allergy Clin. Immunol. 1996, 98, 371-381. [CrossRef]

46. Reimert, C.M.; Skov, P.S.; Poulsen, L.K. A microtiter assay for activation of eosinophils. Simultaneous monitoring of eosinophil adhesion and degranulation. Allergy 1998, 53, 129-138. [CrossRef] [PubMed]

47. Esnault, S.; Johansson, M.W.; Kelly, E.A.; Koenderman, L.; Mosher, D.F.; Jarjour, N.N. IL-3 up-regulates and activates human eosinophil CD32 and $\alpha \mathrm{M} \beta 2$ integrin causing degranulation. Clin. Exp. Allergy 2017, 47, 488-498. [CrossRef] 
48. Spencer, L.A.; Bonjour, K.; Melo, R.C.; Weller, P.F. Eosinophil secretion of granule-derived cytokines. Front. Immunol. 2014,5 , 496. [CrossRef]

49. Martinez-Moczygemba, M.; Huston, D.P. Biology of common beta receptor-signaling cytokines: IL-3, IL-5, and GM-CSF. J. Allergy Clin. Immunol. 2003, 112, 653-665, quiz 66.

50. Bagnasco, D.; Ferrando, M.; Varricchi, G.; Puggioni, F.; Passalacqua, G.; Canonica, G.W. Anti-Interleukin 5 (IL-5) and IL-5Ra Biological Drugs: Efficacy, Safety, and Future Perspectives in Severe Eosinophilic Asthma. Front. Med. 2017, 4, 135. [CrossRef]

51. Pavord, I.D.; Korn, S.; Howarth, P.; Bleecker, E.R.; Buhl, R.; Keene, O.N.; Ortega, H.; Chanez, P. Mepolizumab for severe eosinophilic asthma (DREAM): A multicentre, double-blind, placebo-controlled trial. Lancet 2012, 380, 651-659. [CrossRef]

52. Ortega, H.G.; Liu, M.C.; Pavord, I.D.; Brusselle, G.G.; FitzGerald, J.M.; Chetta, A.; Humbert, M.; Katz, L.E.; Keene, O.N.; Yancey, S.W.; et al. Mepolizumab treatment in patients with severe eosinophilic asthma. N. Engl. J. Med. 2014, 371, 1198-1207. [CrossRef]

53. Bel, E.H.; Wenzel, S.E.; Thompson, P.J.; Prazma, C.M.; Keene, O.N.; Yancey, S.W.; Ortega, H.G.; Pavord, I.D. Oral glucocorticoidsparing effect of mepolizumab in eosinophilic asthma. N. Engl. J. Med. 2014, 371, 1189-1197. [CrossRef]

54. Bernstein, J.A.; Virchow, J.C.; Murphy, K.; Maspero, J.F.; Jacobs, J.; Adir, Y.; Humbert, M.; Castro, M.; Marsteller, D.A.; McElhattan, J.; et al. Effect of fixed-dose subcutaneous reslizumab on asthma exacerbations in patients with severe uncontrolled asthma and corticosteroid sparing in patients with oral corticosteroid-dependent asthma: Results from two phase 3, randomised, double-blind, placebo-controlled trials. Lancet Respir. Med. 2020, 8, 461-474. [PubMed]

55. Kolbeck, R.; Kozhich, A.; Koike, M.; Peng, L.; Andersson, C.K.; Damschroder, M.M.; Reed, J.L.; Woods, R.; Dall'Acqua, W.W.; Stephens, G.L.; et al. MEDI-563, a humanized anti-IL-5 receptor alpha mAb with enhanced antibody-dependent cell-mediated cytotoxicity function. J. Allergy Clin. Immunol. 2010, 125, 1344-1353.e2. [CrossRef]

56. Mukherjee, M.; Lim, H.F.; Thomas, S.; Miller, D.; Kjarsgaard, M.; Tan, B.; Sehmi, R.; Khalidi, N.; Nair, P. Airway autoimmune responses in severe eosinophilic asthma following low-dose Mepolizumab therapy. Allergy Asthma Clin. Immunol. 2017, 13, 1-6. [CrossRef] [PubMed]

57. Ghazi, A.; Trikha, A.; Calhoun, W.J. Benralizumab-a humanized mAb to IL-5R $\alpha$ with enhanced antibody-dependent cell-mediated cytotoxicity-A novel approach for the treatment of asthma. Expert Opin. Biol. Ther. 2012, 12, 113-118. [CrossRef] [PubMed]

58. Bleecker, E.R.; FitzGerald, J.M.; Chanez, P.; Papi, A.; Weinstein, S.F.; Barker, P.; Sproule, S.; Gilmartin, G.; Aurivillius, M.; Werkström, V.; et al. Efficacy and safety of benralizumab for patients with severe asthma uncontrolled with high-dosage inhaled corticosteroids and long-acting $\beta(2)$-agonists (SIROCCO): A randomised, multicentre, placebo-controlled phase 3 trial. Lancet 2016, 388, 2115-2127. [CrossRef]

59. FitzGerald, J.M.; Bleecker, E.R.; Nair, P.; Korn, S.; Ohta, K.; Lommatzsch, M.; Ferguson, G.T.; Busse, W.W.; Barker, P.; Sproule, S.; et al. Benralizumab, an anti-interleukin-5 receptor $\alpha$ monoclonal antibody, as add-on treatment for patients with severe, uncontrolled, eosinophilic asthma (CALIMA): A randomised, double-blind, placebo-controlled phase 3 trial. Lancet 2016, 388, 2128-2141. [CrossRef]

60. Nair, P.; Barker, P.; Goldman, M. Glucocorticoid Sparing of Benralizumab in Asthma. N. Engl. J. Med. 2017, 377, 1205. [PubMed]

61. Ferguson, G.T.; FitzGerald, J.M.; Bleecker, E.R.; Laviolette, M.; Bernstein, D.; LaForce, C.; Mansfield, L.; Barker, P.; Wu, Y.; Jison, M.; et al. Benralizumab for patients with mild to moderate, persistent asthma (BISE): A randomised, double-blind, placebo-controlled, phase 3 trial. Lancet Respir. Med. 2017, 5, 568-576. [CrossRef]

62. Busse, W.; Chupp, G.; Nagase, H.; Albers, F.C.; Doyle, S.; Shen, Q.; Bratton, D.J.; Gunsoy, N.B. Anti-IL-5 treatments in patients with severe asthma by blood eosinophil thresholds: Indirect treatment comparison. J. Allergy Clin. Immunol. 2019, 143, 190-200.e20. [CrossRef]

63. Bourdin, A.; Husereau, D.; Molinari, N.; Golam, S.; Siddiqui, M.K.; Lindner, L.; Xu, X. Matching-adjusted indirect comparison of benralizumab versus interleukin-5 inhibitors for the treatment of severe asthma: A systematic review. Eur. Respir. J. 2018, 52, 1801393. [CrossRef] [PubMed]

64. Asquith, K.L.; Ramshaw, H.S.; Hansbro, P.M.; Beagley, K.W.; Lopez, A.F.; Foster, P.S. The IL-3/IL-5/GM-CSF common receptor plays a pivotal role in the regulation of Th2 immunity and allergic airway inflammation. J. Immunol. 2008, 180, $1199-1206$. [CrossRef] [PubMed]

65. Panousis, C.; Dhagat, U.; Edwards, K.M.; Rayzman, V.; Hardy, M.P.; Braley, H.; Gauvreau, G.M.; Hercus, T.R.; Smith, S.; Sehmi, R.; et al. CSL311, a novel, potent, therapeutic monoclonal antibody for the treatment of diseases mediated by the common $\beta$ chain of the IL-3, GM-CSF and IL-5 receptors. MAbs 2016, 8, 436-453. [CrossRef] [PubMed]

66. Yip, K.H.; Wilson, N.J.; Pant, H.; Brown, C.L.; Busfield, S.; Ng, M.; Alhamdoosh, M.; Woodman, N.; Schembri, M.; Tumes, D.J.; et al. Anti- $\beta(c)$ mAb CSL311 inhibits human nasal polyp pathophysiology in a humanized mouse xenograft model. Allergy 2020, 75, 475-478. [CrossRef]

67. Junttila, I.S.; Mizukami, K.; Dickensheets, H.; Meier-Schellersheim, M.; Yamane, H.; Donnelly, R.P.; Paul, W.E. Tuning sensitivity to IL-4 and IL-13: Differential expression of IL-4Ralpha, IL-13Ralpha1, and gammac regulates relative cytokine sensitivity. J. Exp. Med. 2008, 205, 2595-2608. [CrossRef]

68. Minty, A.; Chalon, P.; Derocq, J.M.; Dumont, X.; Guillemot, J.C.; Kaghad, M.; Labit, C.; Leplatois, P.; Liauzun, P.; Miloux, B.; et al. Interleukin-13 is a new human lymphokine regulating inflammatory and immune responses. Nature 1993, 362, $248-250$. [CrossRef]

69. Zurawski, G.; de Vries, J.E. Interleukin 13, an interleukin 4-like cytokine that acts on monocytes and B cells, but not on T cells. Immunol. Today 1994, 15, 19-26. [CrossRef] 
70. Corry, D.B. IL-13 in allergy: Home at last. Curr. Opin. Immunol. 1999, 11, 610-614. [CrossRef]

71. Burd, P.R.; Thompson, W.C.; Max, E.E.; Mills, F.C. Activated mast cells produce interleukin 13. J. Exp. Med. 1995, 181, 1373-1380. [CrossRef]

72. Li, H.; Sim, T.C.; Alam, R. IL-13 released by and localized in human basophils. J. Immunol. 1996, 156, $4833-4838$.

73. Wills-Karp, M.; Luyimbazi, J.; Xu, X.; Schofield, B.; Neben, T.Y.; Karp, C.L.; Donaldson, D.D. Interleukin-13: Central mediator of allergic asthma. Science 1998, 282, 2258-2261. [CrossRef]

74. Luttmann, W.; Knoechel, B.; Foerster, M.; Matthys, H.; Virchow, J.C.; Jr Kroegel, C. Activation of human eosinophils by IL-13 Induction of CD69 surface antigen, its relationship to messenger RNA expression, and promotion of cellular viability. J. Immunol. 1996, 157, 1678-1683.

75. Kalayci, O.; Sonna, L.A.; Woodruff, P.G.; Camargo, C.A.; Luster, A.D., Jr.; Lilly, C.M. Monocyte chemotactic protein-4 (MCP-4; CCL-13): A biomarker of asthma. J. Asthma 2004, 41, 27-33. [CrossRef]

76. Leung, T.F.; Wong, C.K.; Chan, I.H.; Ip, W.K.; Lam, C.W.; Wong, G.W. Plasma concentration of thymus and activation-regulated chemokine is elevated in childhood asthma. J. Allergy Clin. Immunol. 2002, 110, 404-409. [CrossRef]

77. Schmid-Grendelmeier, P.; Altznauer, F.; Fischer, B.; Bizer, C.; Straumann, A.; Menz, G.; Blaser, K.; Wüthrich, B.; Simon, H.U. Eosinophils express functional IL-13 in eosinophilic inflammatory diseases. J. Immunol. 2002, 169, 1021-1027. [CrossRef] [PubMed]

78. Gauvreau, G.M.; Boulet, L.-P.; Cockcroft, D.W.; Fitzgerald, J.M.; Carlsten, C.; Davis, B.E.; Deschesnes, F.; Duong, M.; Durn, B.L.; Howie, K.J. Effects of interleukin-13 blockade on allergen-induced airway responses in mild atopic asthma. Am. J. Respir. Crit. Care Med. 2011, 183, 1007-1014. [CrossRef]

79. Wenzel, S.; Wilbraham, D.; Fuller, R.; Getz, E.B.; Longphre, M. Effect of an interleukin-4 variant on late phase asthmatic response to allergen challenge in asthmatic patients: Results of two phase 2a studies. Lancet 2007, 370, 1422-1431. [CrossRef]

80. Scheerens, H.; Arron, J.R.; Zheng, Y.; Putnam, W.S.; Erickson, R.W.; Choy, D.F.; Harris, J.M.; Lee, J.; Jarjour, N.N.; Matthews, J.G. The effects of lebrikizumab in patients with mild asthma following whole lung allergen challenge. Clin. Exp. Allergy 2014, 44, 38-46. [CrossRef] [PubMed]

81. Austin, C.D.; Gonzalez Edick, M.; Ferrando, R.E.; Solon, M.; Baca, M.; Mesh, K.; Bradding, P.; Gauvreau, G.M.; Sumino, K.; FitzGerald, J.M. A randomized, placebo-controlled trial evaluating effects of lebrikizumab on airway eosinophilic inflammation and remodelling in uncontrolled asthma (CLAVIER). Clin. Exp. Allergy 2020, 50, 1342-1351. [CrossRef] [PubMed]

82. Busse, W.W.; Brusselle, G.G.; Korn, S.; Kuna, P.; Magnan, A.; Cohen, D.; Bowen, K.; Piechowiak, T.; Wang, M.M.; Colice, G. Tralokinumab did not demonstrate oral corticosteroid-sparing effects in severe asthma. Eur. Respir. J. 2019, 53, 1800948. [CrossRef]

83. Russell, R.J.; Chachi, L.; FitzGerald, J.M.; Backer, V.; Olivenstein, R.; Titlestad, I.L.; Ulrik, C.S.; Harrison, T.; Singh, D.; Chaudhuri, R. Effect of tralokinumab, an interleukin-13 neutralising monoclonal antibody, on eosinophilic airway inflammation in uncontrolled moderate-to-severe asthma (MESOS): A multicentre, double-blind, randomised, placebo-controlled phase 2 trial. Lancet Respir. Med. 2018, 6, 499-510. [CrossRef]

84. Hanania, N.A.; Korenblat, P.; Chapman, K.R.; Bateman, E.D.; Kopecky, P.; Paggiaro, P.; Yokoyama, A.; Olsson, J.; Gray, S.; Holweg, C.T. Efficacy and safety of lebrikizumab in patients with uncontrolled asthma (LAVOLTA I and LAVOLTA II): Replicate, phase 3 , randomised, double-blind, placebo-controlled trials. Lancet Respir. Med. 2016, 4, 781-796. [CrossRef]

85. Wenzel, S.; Ford, L.; Pearlman, D.; Spector, S.; Sher, L.; Skobieranda, F.; Wang, L.; Kirkesseli, S.; Rocklin, R.; Bock, B. Dupilumab in persistent asthma with elevated eosinophil levels. N. Engl. J. Med. 2013, 368, 2455-2466. [CrossRef] [PubMed]

86. Wenzel, S.; Castro, M.; Corren, J.; Maspero, J.; Wang, L.; Zhang, B.; Pirozzi, G.; Sutherland, E.R.; Evans, R.R.; Joish, V.N. Dupilumab efficacy and safety in adults with uncontrolled persistent asthma despite use of medium-to-high-dose inhaled corticosteroids plus a long-acting $\beta 2$ agonist: A randomised double-blind placebo-controlled pivotal phase $2 \mathrm{~b}$ dose-ranging trial. Lancet 2016, 388, 31-44. [CrossRef]

87. Pavord, I.D.; Siddiqui, S.; Papi, A.; Corren, J.; Sher, L.D.; Bardin, P.; Langton, D.; Park, H.S.; Rice, M.S.; Deniz, Y. Dupilumab Efficacy in Patients Stratified by Baseline Treatment Intensity and Lung Function. J. Asthma Allergy 2020, 13, 701-711. [CrossRef] [PubMed]

88. Bourdin, A.; Papi, A.A.; Corren, J.; Virchow, J.C.; Rice, M.S.; Deniz, Y.; Djandji, M.; Rowe, P.; Pavord, I.D. Dupilumab is effective in type 2-high asthma patients receiving high-dose inhaled corticosteroids at baseline. Allergy 2021, 76, 269-280. [CrossRef] [PubMed]

89. Castro, M.; Corren, J.; Pavord, I.D.; Maspero, J.; Wenzel, S.; Rabe, K.F.; Busse, W.W.; Ford, L.; Sher, L.; FitzGerald, J.M. Dupilumab Efficacy and Safety in Moderate-to-Severe Uncontrolled Asthma. N. Engl. J. Med. 2018, 378, 2486-2496. [CrossRef]

90. Ponath, P.D.; Qin, S.; Ringler, D.J.; Clark-Lewis, I.; Wang, J.; Kassam, N.; Smith, H.; Shi, X.; Gonzalo, J.A.; Newman, W. Cloning of the human eosinophil chemoattractant, eotaxin. Expression, receptor binding, and functional properties suggest a mechanism for the selective recruitment of eosinophils. J. Clin. Investig. 1996, 97, 604-612. [CrossRef] [PubMed]

91. Humbles, A.A.; Lu, B.; Friend, D.S.; Okinaga, S.; Lora, J.; Al-Garawi, A.; Martin, T.R.; Gerard, N.P.; Gerard, C. The murine CCR3 receptor regulates both the role of eosinophils and mast cells in allergen-induced airway inflammation and hyperresponsiveness. Proc. Natl. Acad. Sci. USA 2002, 99, 1479-1484. [CrossRef]

92. Garcia-Zepeda, E.A.; Rothenberg, M.E.; Ownbey, R.T.; Celestin, J.; Leder, P.; Luster, A.D. Human eotaxin is a specific chemoattractant for eosinophil cells and provides a new mechanism to explain tissue eosinophilia. Nat. Med. 1996, 2, 449-456. [CrossRef] 
93. Fulkerson, P.C.; Fischetti, C.A.; McBride, M.L.; Hassman, L.M.; Hogan, S.P.; Rothenberg, M.E. A central regulatory role for eosinophils and the eotaxin/CCR3 axis in chronic experimental allergic airway inflammation. Proc. Natl. Acad. Sci. USA 2006, 103, 16418-16423. [CrossRef]

94. Ahmadi, Z.; Hassanshahi, G.; Khorramdelazad, H.; Zainodini, N.; Koochakzadeh, L. An Overlook to the Characteristics and Roles Played by Eotaxin Network in the Pathophysiology of Food Allergies: Allergic Asthma and Atopic Dermatitis. Inflammation 2016, 39, 1253-1267. [CrossRef] [PubMed]

95. Gauvreau, G.M.; El-Gammal, A.I.; O’Byrne, P.M. Allergen-induced airway responses. Eur. Respir. J. 2015, 46, 819-831. [CrossRef]

96. Boulet, L.P.; Gauvreau, G.; Boulay, M.E.; O’Byrne, P.; Cockcroft, D.W.; Clinical Investigative Collaboration. The allergen bronchoprovocation model: An important tool for the investigation of new asthma anti-inflammatory therapies. Allergy 2007, 62, 1101-1110. [CrossRef] [PubMed]

97. Gauvreau, G.M.; O’Byrne, P.M.; Boulet, L.P.; Wang, Y.; Cockcroft, D.; Bigler, J.; FitzGerald, J.M.; Boedigheimer, M.; Davis, B.E.; Dias, C. Effects of an anti-TSLP antibody on allergen-induced asthmatic responses. N. Engl. J. Med. 2014, 370, $2102-2110$. [CrossRef]

98. Gauvreau, G.M.; FitzGerald, J.M.; Boulet, L.P.; Watson, R.M.; Hui, L.; Villineuve, H.; Scime, T.X.; Schlatman, A.R.; Obminski, C.; Kum, J. The effects of a CCR3 inhibitor, AXP1275, on allergen-induced airway responses in adults with mild-to-moderate atopic asthma. Clin. Exp. Allergy 2018, 48, 445-451. [CrossRef]

99. Neighbour, H.; Boulet, L.P.; Lemiere, C.; Sehmi, R.; Leigh, R.; Sousa, A.R.; Martin, J.; Dallow, N.; Gilbert, J.; Allen, A. Safety and efficacy of an oral CCR3 antagonist in patients with asthma and eosinophilic bronchitis: A randomized, placebo-controlled clinical trial. Clin. Exp. Allergy 2014, 44, 508-516. [CrossRef] [PubMed]

100. Gauvreau, G.M.; Boulet, L.P.; Cockcroft, D.W.; Baatjes, A.; Cote, J.; Deschesnes, F.; Davis, B.; Strinich, T.; Howie, K.; Duong, M. Antisense therapy against CCR3 and the common beta chain attenuates allergen-induced eosinophilic responses. Am. J. Respir. Crit. Care Med. 2008, 177, 952-958. [CrossRef] [PubMed]

101. Gauvreau, G.M.; Pageau, R.; Séguin, R.; Carballo, D.; Gauthier, J.; D’Anjou, H.; Campbell, H.; Watson, R.; Mistry, M.; Parry-Billings, M. Dose-response effects of TPI ASM8 in asthmatics after allergen. Allergy 2011, 66, 1242-1248. [CrossRef]

102. Song, D.J.; Shim, M.H.; Lee, N.; Yoo, Y.; Choung, J.T. CCR3 Monoclonal Antibody Inhibits Eosinophilic Inflammation and Mucosal. Injury in a Mouse Model of Eosinophilic Gastroenteritis. Allergy Asthma Immunol. Res. 2017, 9, 360-367. [CrossRef]

103. Shen, H.H.; Xu, F.; Zhang, G.S.; Wang, S.B.; Xu, W.H. CCR3 monoclonal antibody inhibits airway eosinophilic inflammation and mucus overproduction in a mouse model of asthma. Acta Pharmacol. Sin. 2006, 27, 1594-1599. [CrossRef] [PubMed]

104. Hirai, H.; Tanaka, K.; Yoshie, O.; Ogawa, K.; Kenmotsu, K.; Takamori, Y.; Ichimasa, M.; Sugamura, K.; Nakamura, M.; Takano, S. Prostaglandin D2 selectively induces chemotaxis in T helper type 2 cells, eosinophils, and basophils via seven-transmembrane receptor CRTH2. J. Exp. Med. 2001, 193, 255-261. [CrossRef] [PubMed]

105. Xue, L.; Barrow, A.; Pettipher, R. Interaction between prostaglandin D and chemoattractant receptor-homologous molecule expressed on Th2 cells mediates cytokine production by Th2 lymphocytes in response to activated mast cells. Clin. Exp. Immunol. 2009, 156, 126-133. [CrossRef] [PubMed]

106. Lukacs, N.W.; Berlin, A.A.; Franz-Bacon, K.; Sásik, R.; Sprague, L.J.; Ly, T.W.; Hardiman, G.; Boehme, S.A.; Bacon, K.B. CRTH2 antagonism significantly ameliorates airway hyperreactivity and downregulates inflammation-induced genes in a mouse model of airway inflammation. Am. J. Physiol. Lung Cell Mol. Physiol. 2008, 295, L767-L779. [CrossRef] [PubMed]

107. Barnes, N.; Pavord, I.; Chuchalin, A.; Bell, J.; Hunter, M.; Lewis, T.; Parker, D.; Payton, M.; Collins, L.P.; Pettipher, R. A randomized, double-blind, placebo-controlled study of the CRTH2 antagonist OC000459 in moderate persistent asthma. Clin. Exp. Allergy 2012, 42, 38-48. [CrossRef]

108. Wenzel, S.E.; Hopkins, R.; Saunders, M.; Chantry, D.; Anderson, L.; Aitchison, R.; Eberhardt, C.; Bell, S.; Cole, J.; Wolfe, J.; et al. Safety and efficacy of ARRY-502, a potent, selective, Oral CRTh2 antagonist, in patients with mild to moderate Th2-driven asthma. J. Allergy Clin. Immunol. 2014, 133, AB4. [CrossRef]

109. Gonem, S.; Berair, R.; Singapuri, A.; Hartley, R.; Laurencin, M.F.M.; Bacher, G.; Holzhauer, B.; Bourne, M.; Mistry, V.; Pavord, I.D. Fevipiprant, a prostaglandin D2 receptor 2 antagonist, in patients with persistent eosinophilic asthma: A single-centre, randomised, double-blind, parallel-group, placebo-controlled trial. Lancet Respir. Med. 2016, 4, 699-707. [CrossRef]

110. Brightling, C.E.; Gaga, M.; Inoue, H.; Li, J.; Maspero, J.; Wenzel, S.; Maitra, S.; Lawrence, D.; Brockhaus, F.; Lehmann, T. Effectiveness of fevipiprant in reducing exacerbations in patients with severe asthma (LUSTER-1 and LUSTER-2): Two phase 3 randomised controlled trials. Lancet Respir. Med. 2021, 9, 43-56. [CrossRef]

111. O'Sullivan, J.A.; Chang, A.T.; Youngblood, B.A.; Bochner, B.S. Eosinophil and mast cell Siglecs: From biology to drug target. J. Leukoc Biol. 2020, 108, 73-81. [CrossRef]

112. Youngblood, B.A.; Brock, E.C.; Leung, J.; Falahati, R.; Bryce, P.J.; Bright, J.; Williams, J.; Shultz, L.D.; Greiner, D.L.; Brehm, M.A. AK002, a Humanized Sialic Acid-Binding Immunoglobulin-Like Lectin-8 Antibody that Induces Antibody-Dependent Cell-Mediated Cytotoxicity against Human Eosinophils and Inhibits Mast Cell-Mediated Anaphylaxis in Mice. Int. Arch. Allergy Immunol. 2019, 180, 91-102. [CrossRef]

113. Youngblood, B.A.; Leung, J.; Falahati, R.; Williams, J.; Schanin, J.; Brock, E.C.; Singh, B.; Chang, A.T.; O'Sullivan, J.A.; Schleimer, R.P. Discovery, Function, and Therapeutic Targeting of Siglec-8. Cells 2020, 10, 19. [CrossRef] [PubMed] 
114. Kerr, S.C.; Gonzalez, J.R.; Schanin, J.; Peters, M.C.; Lambrecht, B.N.; Brock, E.C.; Charbit, A.; Ansel, K.M.; Youngblood, B.A.; Fahy, J.V. An anti-siglec-8 antibody depletes sputum eosinophils from asthmatic subjects and inhibits lung mast cells. Clin. Exp. Allergy 2020, 50, 904-914. [CrossRef]

115. Altrichter, S.; Staubach, P.; Pasha, M.; Rasmussen, H.; Singh, B.; Chang, A.; Bernstein, J.; Siebenhaar, F.; Maurer, M. Efficacy and safety data of AK002, an anti-Siglec-8 monoclonal antibody, in patients with multiple forms of uncontrolled chronic urticaria (CU): Results from an open-label phase 2a study. Allergy 2019, 74, 117-129.

116. Dellon, E.S.; Peterson, K.A.; Murray, J.A.; Falk, G.W.; Gonsalves, N.; Chehade, M.; Genta, R.M.; Leung, J.; Khoury, P.; Klion, A.D. Anti-Siglec-8 Antibody for Eosinophilic Gastritis and Duodenitis. N. Engl. J. Med. 2020, 383, 1624-1634. [CrossRef]

117. Sel, S.; Wegmann, M.; Dicke, T.; Henke, W.; Yildirim, A.O.; Renz, H.; Garn, H. Effective prevention and therapy of experimental allergic asthma using a GATA-3-specific DNAzyme. J. Allergy Clin. Immunol. 2008, 121, 910-916.e5. [CrossRef]

118. Ghonim, M.A.; Pyakurel, K.; Ju, J.; Rodriguez, P.C.; Lammi, M.R.; Davis, C.; Abughazleh, M.Q.; Mansy, M.S.; Naura, A.S.; Boulares, A.H. DNA-dependent protein kinase inhibition blocks asthma in mice and human endothelial and CD4 ${ }^{+} \mathrm{T}_{-}$cell function without causing severe combined immunodeficiency. J. Allergy Clin. Immunol. 2015, 135, 425-440. [CrossRef]

119. Klein-Hessling, S.; Jha, M.K.; Santner-Nanan, B.; Berberich-Siebelt, F.; Baumruker, T.; Schimpl, A.; Serfling, E. Protein kinase A regulates GATA-3-dependent activation of IL-5 gene expression in Th2 cells. J. Immunol. 2003, 170, 2956-2961. [CrossRef] [PubMed]

120. Nakamura, Y.; Ghaffar, O.; Olivenstein, R.; Taha, R.A.; Soussi-Gounni, A.; Zhang, D.H.; Ray, A.; Hamid, Q. Gene expression of the GATA-3 transcription factor is increased in atopic asthma. J. Allergy Clin. Immunol. 1999, 103 Pt 1, 215-222. [CrossRef]

121. Erpenbeck, V.J.; Hohlfeld, J.M.; Discher, M.; Krentel, H.; Hagenberg, A.; Braun, A.; Krug, N. Increased messenger RNA expression of c-maf and GATA-3 after segmental allergen challenge in allergic asthmatics. Chest 2003, 123 (Suppl. S3), 370s-371s. [CrossRef] [PubMed]

122. Taha, R.; Hamid, Q.; Cameron, L.; Olivenstein, R. T helper type 2 cytokine receptors and associated transcription factors GATA-3, c-MAF, and signal transducer and activator of transcription factor-6 in induced sputum of atopic asthmatic patients. Chest 2003, 123, 2074-2082. [CrossRef] [PubMed]

123. Erpenbeck, V.J.; Hagenberg, A.; Krentel, H.; Discher, M.; Braun, A.; Hohlfeld, J.M.; Krug, N. Regulation of GATA-3, c-maf and T-bet mRNA expression in bronchoalveolar lavage cells and bronchial biopsies after segmental allergen challenge. Int. Arch Allergy Immunol. 2006, 139, 306-316. [CrossRef] [PubMed]

124. Dicke, T.; Pali-Schöll, I.; Kaufmann, A.; Bauer, S.; Renz, H.; Garn, H. Absence of unspecific innate immune cell activation by GATA-3-specific DNAzymes. Nucleic Acid Ther. 2012, 22, 117-126. [CrossRef]

125. Fuhst, R.; Runge, F.; Buschmann, J.; Ernst, H.; Praechter, C.; Hansen, T.; von Erichsen, J.; Turowska, A.; Hoymann, H.G.; Müller, M. Toxicity profile of the GATA-3-specific DNAzyme hgd40 after inhalation exposure. Pulm. Pharmacol. Ther. 2013, 26, 281-289. [CrossRef] [PubMed]

126. Sulaiman, I.; Lim, J.C.; Soo, H.L.; Stanslas, J. Molecularly targeted therapies for asthma: Current development, challenges and potential clinical translation. Pulm. Pharmacol. Ther. 2016, 40, 52-68. [CrossRef] [PubMed]

127. Garn, H.; Renz, H. GATA-3-specific DNAzyme-A novel approach for stratified asthma therapy. Eur. J. Immunol. 2017, 47, 22-30. [CrossRef]

128. Turowska, A.; Librizzi, D.; Baumgartl, N.; Kuhlmann, J.; Dicke, T.; Merkel, O.; Homburg, U.; Höffken, H.; Renz, H.; Garn, H. Biodistribution of the GATA-3-specific DNAzyme hgd40 after inhalative exposure in mice, rats and dogs. Toxicol. Appl. Pharmacol. 2013, 272, 365-372. [CrossRef]

129. Krug, N.; Hohlfeld, J.M.; Kirsten, A.M.; Kornmann, O.; Beeh, K.M.; Kappeler, D.; Korn, S.; Ignatenko, S.; Timmer, W.; Rogon, C. Allergen-induced asthmatic responses modified by a GATA3-specific DNAzyme. N. Engl. J. Med. 2015, 372, 1987-1995. [CrossRef]

130. Greulich, T.; Hohlfeld, J.M.; Neuser, P.; Lueer, K.; Klemmer, A.; Schade-Brittinger, C.; Harnisch, S.; Garn, H.; Renz, H.; Homburg, U. A GATA3-specific DNAzyme attenuates sputum eosinophilia in eosinophilic COPD patients: A feasibility randomized clinical trial. Respir. Res. 2018, 19, 55. [CrossRef]

131. Allakhverdi, Z.; Comeau, M.R.; Jessup, H.K.; Yoon, B.R.; Brewer, A.; Chartier, S.; Paquette, N.; Ziegler, S.F.; Sarfati, M.; Delespesse, G. Thymic stromal lymphopoietin is released by human epithelial cells in response to microbes, trauma, or inflammation and potently activates mast cells. J. Exp. Med. 2007, 204, 253-258. [CrossRef]

132. Soumelis, V.; Reche, P.A.; Kanzler, H.; Yuan, W.; Edward, G.; Homey, B.; Gilliet, M.; Ho, S.; Antonenko, S.; Lauerma, A. Human epithelial cells trigger dendritic cell-mediated allergic inflammation by producing TSLP. Nat. Immunol. 2002, 3, 673-680. [CrossRef]

133. Wong, C.K.; Hu, S.; Cheung, P.F.; Lam, C.W. Thymic stromal lymphopoietin induces chemotactic and prosurvival effects in eosinophils: Implications in allergic inflammation. Am. J. Respir. Cell Mol. Biol. 2010, 43, 305-315. [CrossRef] [PubMed]

134. Ying, S.; O'Connor, B.; Ratoff, J.; Meng, Q.; Mallett, K.; Cousins, D.; Robinson, D.; Zhang, G.; Zhao, J.; Lee, T.H. Thymic stromal lymphopoietin expression is increased in asthmatic airways and correlates with expression of Th2-attracting chemokines and disease severity. J. Immunol. 2005, 174, 8183-8190. [CrossRef]

135. Shikotra, A.; Choy, D.F.; Ohri, C.M.; Doran, E.; Butler, C.; Hargadon, B.; Shelley, M.; Abbas, A.R.; Austin, C.D.; Jackman, J. Increased expression of immunoreactive thymic stromal lymphopoietin in patients with severe asthma. J. Allergy Clin. Immunol. 2012, 129, e1-e9. [CrossRef] [PubMed] 
136. Toki, S.; Goleniewska, K.; Zhang, J.; Zhou, W.; Newcomb, D.C.; Zhou, B.; Kita, H.; Boyd, K.L.; Peebles, R.S., Jr. TSLP and IL-33 reciprocally promote each other's lung protein expression and ILC2 receptor expression to enhance innate type-2 airway inflammation. Allergy 2020, 75, 1606-1617. [CrossRef] [PubMed]

137. Gauvreau, G.M.; Hohlfeld, J.M.; Grant, S.; Jain, M.; Cabanski, M.; Pertel, P.; Boulet, L.P.; Cockcroft, D.W.; Davis, B.; Fitzgerald, J.M.; et al. Efficacy and Safety of an Inhaled Anti-TSLP Antibody Fragment in Adults with Mild Atopic Asthma. Am. J. Respir. Crit. Care Med. 2020, 201, A4207.

138. Kabata, H.; Moro, K.; Fukunaga, K.; Suzuki, Y.; Miyata, J.; Masaki, K.; Betsuyaku, T.; Koyasu, S.; Asano, K. Thymic stromal lymphopoietin induces corticosteroid resistance in natural helper cells during airway inflammation. Nat. Commun. 2013, 4, 2675. [CrossRef] [PubMed]

139. Verstraete, K.; Peelman, F.; Braun, H.; Lopez, J.; Van Rompaey, D.; Dansercoer, A.; Vandenberghe, I.; Pauwels, K.; Tavernier, J.; Lambrecht, B.N. Structure and antagonism of the receptor complex mediated by human TSLP in allergy and asthma. Nat. Commun. 2017, 8, 14937. [CrossRef]

140. Corren, J.; Parnes, J.R.; Wang, L.; Mo, M.; Roseti, S.L.; Griffiths, J.M.; van der Merwe, R. Tezepelumab in Adults with Uncontrolled Asthma. N. Engl. J. Med. 2017, 377, 936-946. [CrossRef] [PubMed]

141. Menzies-Gow, A.; Corren, J.; Bourdin, A.; Chupp, G.; Israel, E.; Griffiths, J.; Hellqvist, Å.; Bowen, K.; Kaur, P.; Almqvist, G. Efficacy and Safety of Tezepelumab in Adults and Adolescents with Severe, Uncontrolled Asthma: Results from the Phase 3 NAVIGATOR Study. J. Allergy Clin. Immunol. 2021, 147, AB249.

142. Bartemes, K.R.; Iijima, K.; Kobayashi, T.; Kephart, G.M.; McKenzie, A.N.; Kita, H. IL-33-responsive lineage- CD25+ CD44(hi) lymphoid cells mediate innate type 2 immunity and allergic inflammation in the lungs. J. Immunol. 2012, 188, 1503-1513. [CrossRef]

143. Guo, Z.; Wu, J.; Zhao, J.; Liu, F.; Chen, Y.; Bi, L.; Liu, S.; Dong, L. IL-33 promotes airway remodeling and is a marker of asthma disease severity. J. Asthma. 2014, 51, 863-869. [CrossRef]

144. Lee, H.Y.; Hur, J.; Kang, H.S.; Choi, J.Y.; Rhee, C.K.; Kang, J.Y.; Kim, Y.K.; Lee, S.Y. Blockade of thymic stromal lymphopoietin and CRTH2 attenuates airway inflammation in a murine model of allergic asthma. Korean J. Intern Med. 2020, 35, 619-629. [CrossRef]

145. Wechsler, M.; Ruddy, M.K.; Pavord, I.D.; Israel, E.; Rabe, K.F.; Abdulai, R.M.; Hu, C.C.; Martincova, R.; Nivens, C.; Amin, N.; et al. SAR440340, An Anti-IL-33 Monoclonal Antibody, Demonstrated a Significant Reduction of LOAC Events and Improved Pre-BD FEV1 in Patients with Moderate to Severe Asthma: Results from the Phase 2 Proof of Concept Study. Am. J. Respir. Cell Mol. Biol. 2020, 201, A4269.

146. Londei, M.; Marquette-Hamoudi, A.; Phenis, K.; Pinkstaff, J.; Sacco, N.; Pavord, I.D. Single-dose Phase 2a trial of etokimab (anti-IL-33) in severe eosinophilic asthma. Allergy 2019, 74, 128.

147. Spits, H.; Artis, D.; Colonna, M.; Diefenbach, A.; Di Santo, J.P.; Eberl, G.; Koyasu, S.; Locksley, R.M.; McKenzie, A.N.; Mebius, R.E. Innate lymphoid cells-a proposal for uniform nomenclature. Nat. Rev. Immunol. 2013, 13, 145-149. [CrossRef] [PubMed]

148. Moro, K.; Yamada, T.; Tanabe, M.; Takeuchi, T.; Ikawa, T.; Kawamoto, H.; Furusawa, J.I.; Ohtani, M.; Fujii, H.; Koyasu, S. Innate production of T(H)2 cytokines by adipose tissue-associated c-Kit(+)Sca-1(+) lymphoid cells. Nature 2010, 463, 540-544. [CrossRef] [PubMed]

149. Mjösberg, J.M.; Trifari, S.; Crellin, N.K.; Peters, C.P.; van Drunen, C.M.; Piet, B.; Fokkens, W.J.; Cupedo, T.; Spits, H. Human IL-25- and IL-33-responsive type 2 innate lymphoid cells are defined by expression of CRTH2 and CD161. Nat. Immunol. 2011, 12, 1055-1062. [CrossRef]

150. Kim, B.S.; Siracusa, M.C.; Saenz, S.A.; Noti, M.; Monticelli, L.A.; Sonnenberg, G.F.; Hepworth, M.R.; Van Voorhees, A.S.; Comeau, M.R.; Artis, D. TSLP elicits IL-33-independent innate lymphoid cell responses to promote skin inflammation. Sci. Transl. Med. 2013, 5, 170ra16. [CrossRef]

151. Bartemes, K.R.; Kephart, G.M.; Fox, S.J.; Kita, H. Enhanced innate type 2 immune response in peripheral blood from patients with asthma. J. Allergy Clin. Immunol. 2014, 134, 671-678.e4. [CrossRef] [PubMed]

152. Zhong, H.; Fan, X.L.; Yu, Q.N.; Qin, Z.L.; Chen, D.; Xu, R.; Chen, D.H.; Lin, Z.B.; Wen, W.; Fu, Q.L. Increased innate type 2 immune response in house dust mite-allergic patients with allergic rhinitis. Clin. Immunol. 2017, 183, 293-299. [CrossRef] [PubMed]

153. Mashiko, S.; Mehta, H.; Bissonnette, R.; Sarfati, M. Increased frequencies of basophils, type 2 innate lymphoid cells and Th2 cells in skin of patients with atopic dermatitis but not psoriasis. J. Dermatol. Sci. 2017, 88, 167-174. [CrossRef] [PubMed]

154. Salimi, M.; Barlow, J.L.; Saunders, S.P.; Xue, L.; Gutowska-Owsiak, D.; Wang, X.; Huang, L.C.; Johnson, D.; Scanlon, S.T.; McKenzie, A.N. A role for IL-25 and IL-33-driven type-2 innate lymphoid cells in atopic dermatitis. J. Exp. Med. 2013, 210, 2939-2950. [CrossRef] [PubMed]

155. Shaw, J.L.; Fakhri, S.; Citardi, M.J.; Porter, P.C.; Corry, D.B.; Kheradmand, F.; Liu, Y.J.; Luong, A. IL-33-responsive innate lymphoid cells are an important source of IL-13 in chronic rhinosinusitis with nasal polyps. Am. J. Respir. Crit. Care Med. 2013, 188, 432-439. [CrossRef]

156. Kwon, B.I.; Hong, S.; Shin, K.; Choi, E.H.; Hwang, J.J.; Lee, S.H. Innate type 2 immunity is associated with eosinophilic pleural effusion in primary spontaneous pneumothorax. Am. J. Respir. Crit. Care Med. 2013, 188, 577-585. [CrossRef] [PubMed]

157. Smith, S.G.; Chen, R.; Kjarsgaard, M.; Huang, C.; Oliveria, J.P.; O’Byrne, P.M.; Gauvreau, G.M.; Boulet, L.-P.; Lemiere, C.; Martin, J. Increased numbers of activated group 2 innate lymphoid cells in the airways of patients with severe asthma and persistent airway eosinophilia. J. Allergy Clin. Immunol. 2016, 137, 75-86.e8. [CrossRef] [PubMed] 
158. Chen, R.; Smith, S.G.; Salter, B.; El-Gammal, A.; Oliveria, J.P.; Obminski, C.; Watson, R.; O’Byrne, P.M.; Gauvreau, G.M.; Sehmi, R. Allergen-induced Increases in Sputum Levels of Group 2 Innate Lymphoid Cells in Subjects with Asthma. Am. J. Respir. Crit. Care Med. 2017, 196, 700-712. [CrossRef] [PubMed]

159. Neill, D.R.; Wong, S.H.; Bellosi, A.; Flynn, R.J.; Daly, M.; Langford, T.K.; Bucks, C.; Kane, C.M.; Fallon, P.G.; Pannell, R. Nuocytes represent a new innate effector leukocyte that mediates type-2 immunity. Nature 2010, 464, 1367-1370. [CrossRef] [PubMed]

160. Halim, T.Y.; Krauss, R.H.; Sun, A.C.; Takei, F. Lung natural helper cells are a critical source of Th2 cell-type cytokines in protease allergen-induced airway inflammation. Immunity 2012, 36, 451-463. [CrossRef]

161. Monticelli, L.A.; Sonnenberg, G.F.; Abt, M.C.; Alenghat, T.; Ziegler, C.G.; Doering, T.A.; Angelosanto, J.M.; Laidlaw, B.J.; Yang, C.Y.; Sathaliyawala, T. Innate lymphoid cells promote lung-tissue homeostasis after infection with influenza virus. Nat. Immunol. 2011, 12, 1045-1054. [CrossRef]

162. Wilhelm, C.; Hirota, K.; Stieglitz, B.; Van Snick, J.; Tolaini, M.; Lahl, K.; Sparwasser, T.; Helmby, H.; Stockinger, B. An IL-9 fate reporter demonstrates the induction of an innate IL-9 response in lung inflammation. Nat. Immunol. 2011, 12, 1071-1077. [CrossRef]

163. Bal, S.M.; Bernink, J.H.; Nagasawa, M.; Groot, J.; Shikhagaie, M.M.; Golebski, K.; Van Drunen, C.M.; Lutter, R.; Jonkers, R.E.; Hombrink, P. IL-1 $\beta$, IL-4 and IL-12 control the fate of group 2 innate lymphoid cells in human airway inflammation in the lungs. Nat. Immunol. 2016, 17, 636-645. [CrossRef] [PubMed]

164. Zhu, Z.; Homer, R.J.; Wang, Z.; Chen, Q.; Geba, G.P.; Wang, J.; Zhang, Y.; Elias, J.A. Pulmonary expression of interleukin-13 causes inflammation, mucus hypersecretion, subepithelial fibrosis, physiologic abnormalities, and eotaxin production. J. Clin. Investig. 1999, 103, 779-788. [CrossRef] [PubMed]

165. Townsend, J.M.; Fallon, G.P.; Matthews, J.D.; Smith, P.; Jolin, E.H.; McKenzie, N.A. IL-9-deficient mice establish fundamental roles for IL-9 in pulmonary mastocytosis and goblet cell hyperplasia but not T cell development. Immunity 2000, 13, 573-583. [CrossRef] 